\title{
Repeated Mu-Opioid Exposure Induces a Novel Form of the Hyperalgesic Priming Model for Transition to Chronic Pain
}

\author{
Dㅣㄹoneia Araldi, Luiz F. Ferrari, and 저on D. Levine \\ Departments of Medicine and Oral Surgery and Division of Neuroscience, University of California at San Francisco, San Francisco, California 94143
}

\begin{abstract}
The primary afferent nociceptor was used as a model system to study mechanisms of pain induced by chronic opioid administration. Repeated intradermal injection of the selective mu-opioid receptor (MOR) agonist DAMGO induced mechanical hyperalgesia and marked prolongation of prostaglandin $\mathrm{E}_{2}\left(\mathrm{PGE}_{2}\right)$ hyperalgesia, a key feature of hyperalgesic priming. However, in contrast to prior studies of priming induced by receptor-mediated (i.e., TNF $\alpha$, NGF, or IL-6 receptor) or direct activation of protein kinase $\mathrm{C} \varepsilon(\mathrm{PKC} \varepsilon)$, the pronociceptive effects of $\mathrm{PGE}_{2}$ in DAMGO-treated rats demonstrated the following: (1) rapid induction $(4 \mathrm{~h}$ compared with $3 \mathrm{~d}$ ); (2) protein kinase A (PKA), rather than PKC $\varepsilon$, dependence; (3) prolongation of hyperalgesia induced by an activator of PKA, 8-bromo cAMP; (4) failure to be reversed by a protein translation inhibitor; (5) priming in females as well as in males; and (6) lack of dependence on the isolectin B4-positive nociceptor. These studies demonstrate a novel form of hyperalgesic priming induced by repeated administration of an agonist at the Gi-protein-coupled MOR to the peripheral terminal of the nociceptor.
\end{abstract}

Key words: $\beta / \gamma$ subunit; chronic pain; hyperalgesia; hyperalgesic priming; mu-opioid receptor

\section{Significance Statement}

The current study demonstrates the molecular mechanisms involved in the sensitization of nociceptors produced by repeated activation of mu-opioid receptors and contributes to our understanding of the painful condition observed in patients submitted to chronic use of opioids.

\section{Introduction}

Repeated exposure to mu-opioid receptor (MOR) agonists can induce, in addition to the craving associated with opioid tolerance and dependence (Aley et al., 1995; Kolesnikov et al., 1996; Aley and Levine, 1997a, 1997b), long-lasting mechanical hyperalgesia, a phenomenon referred to as opioid-induced hyperalgesia (OIH) (Mao, 2002; Angst and Clark, 2006; Lee et al., 2011). Despite its potential clinical importance, the mechanism underlying OIH is still not well understood. Others (Vanderah et al., 2001; Mao, 2002; Ossipov et al., 2005; Chu et al., 2008; Chen et al., 2010) and we (Aley et al., 1995; Aley and Levine, 1997a, 1997b; Joseph et al., 2010) have used the MOR-containing primary afferent nociceptor as a model system to study the mechanism

\footnotetext{
Received April 29, 2015; revised July 6, 2015; accepted July 31, 2015.

Author contributions: D.A., L.F.F., and J.D.L. designed research; D.A., and L.F.F. performed research; D.A., analyzed data; D.A., L.F.F., and J.D.L. wrote the paper.

This work was funded by the National Institutes of Health (Grant NS084545).

The authors declare no competing financial interests.

Correspondence should be addressed to Dr. Jon D. Levine, Departments of Medicine and Oral Surgery and Division

of Neuroscience, University of California, San Francisco, 521 Parnassus Avenue, San Francisco, CA 94143-0440.

E-mail: Jon.Levine@ucsf.edu.

DOI:10.1523/JNEUROSCI.1673-15.2015

Copyright $\odot 2015$ the authors $\quad 0270-6474 / 15 / 3512502-16 \$ 15.00 / 0$
}

underlying the tolerance, dependence, and pronociceptive effect of chronic opioid administration (Aley et al., 1995; Aley and Levine, 1997a, 1997b; Ossipov et al., 2005; Chu et al., 2008; Chen et al., 2010; Joseph et al., 2010).

In the present experiments, we evaluated the hypothesis that the mechanical hyperalgesia induced by repeated exposure to a MOR-selective agonist reflects a form of hyperalgesic priming (Aley et al., 2000; Joseph et al., 2010), a model of the transition to chronic pain. Classical hyperalgesic priming is induced by activation of receptors for pronociceptive mediators that signal via protein kinase $\mathrm{C} \varepsilon(\mathrm{PKC} \varepsilon$ ) or by direct activation of $\mathrm{PKC} \varepsilon$ in the peripheral terminal of the nociceptor (Aley et al., 2000; Parada et al., 2003b). In the PKC $\varepsilon$-primed nociceptor, exposure to prostaglandin $\mathrm{E}_{2}\left(\mathrm{PGE}_{2}\right)$ and other pronociceptive mediators produces markedly prolonged, $\mathrm{PKC} \varepsilon$-dependent mechanical hyperalgesia mediated by isolectin B4-positive (IB4 ${ }^{+}$) nociceptors (Joseph and Levine, 2010a), which can be reversed by the administration of inhibitors of protein translation to the peripheral terminal of the primed nociceptor (Ferrari et al., 2013b) in male but not female rats (Joseph et al., 2003). We report that repeated administration of DAMGO induces PKA-dependent, rather than $\mathrm{PKC} \varepsilon$-dependent, prolongation of $\mathrm{PGE}_{2}$ hyperalgesia independently of protein translation in the peripheral terminal of the 
A
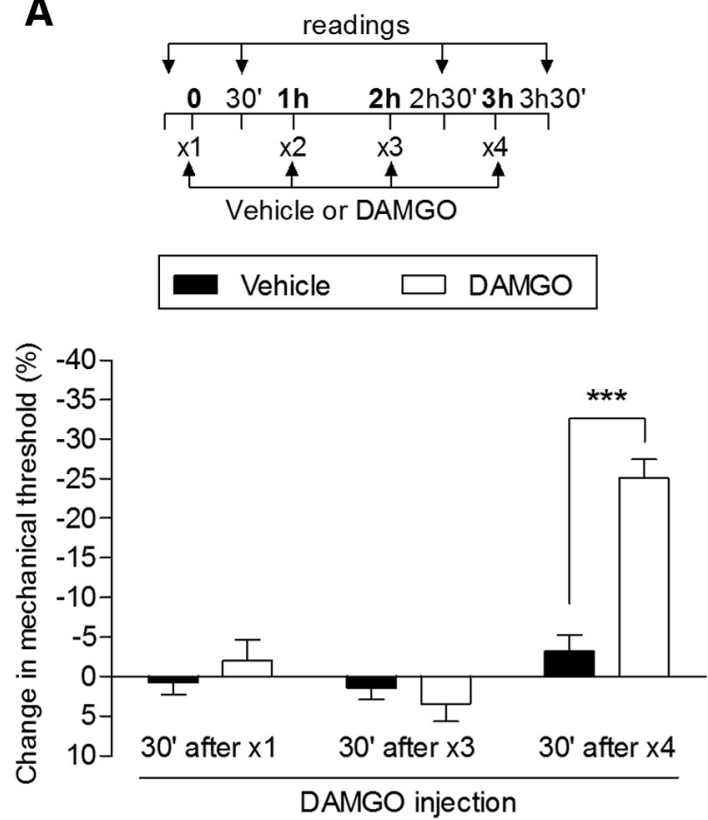

C
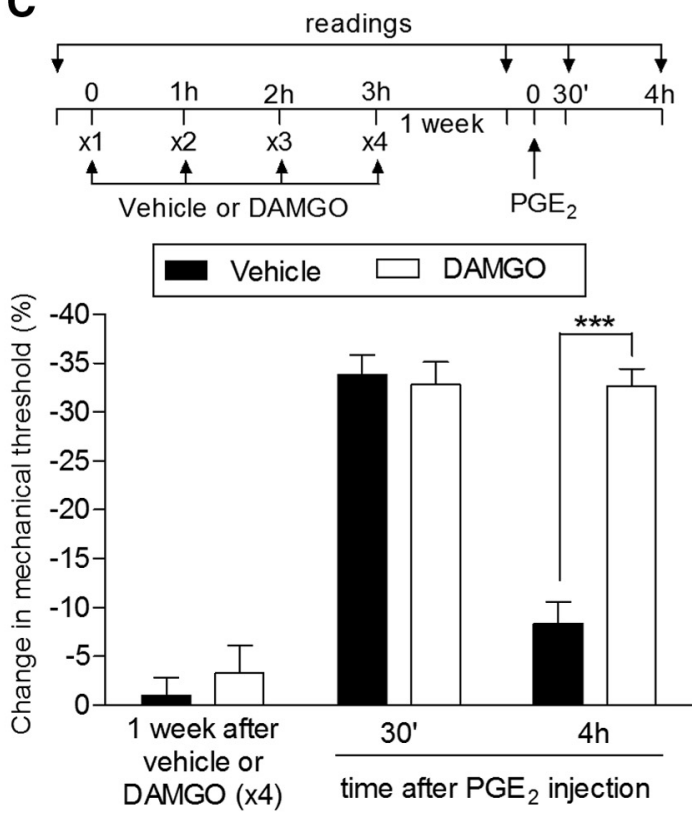

B
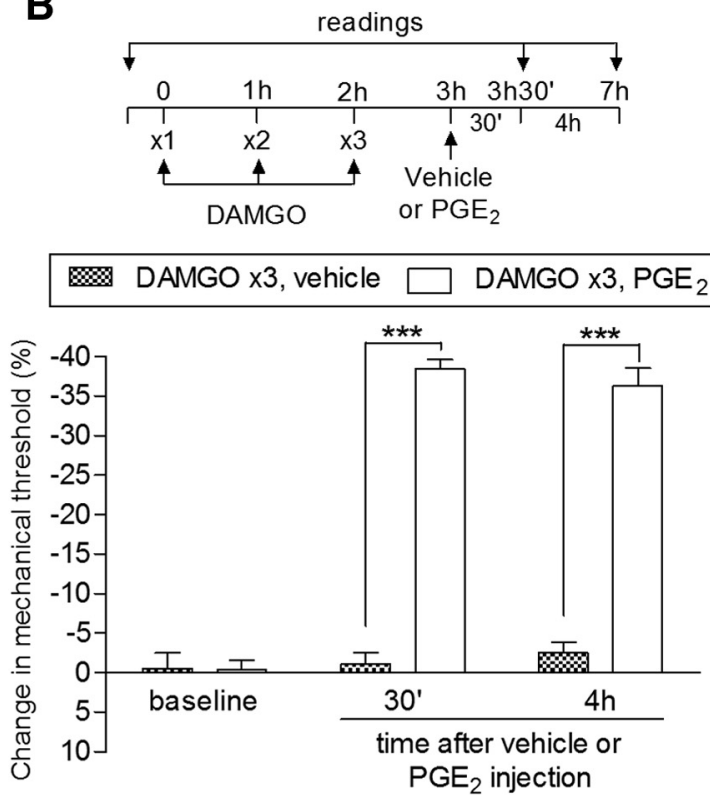

D
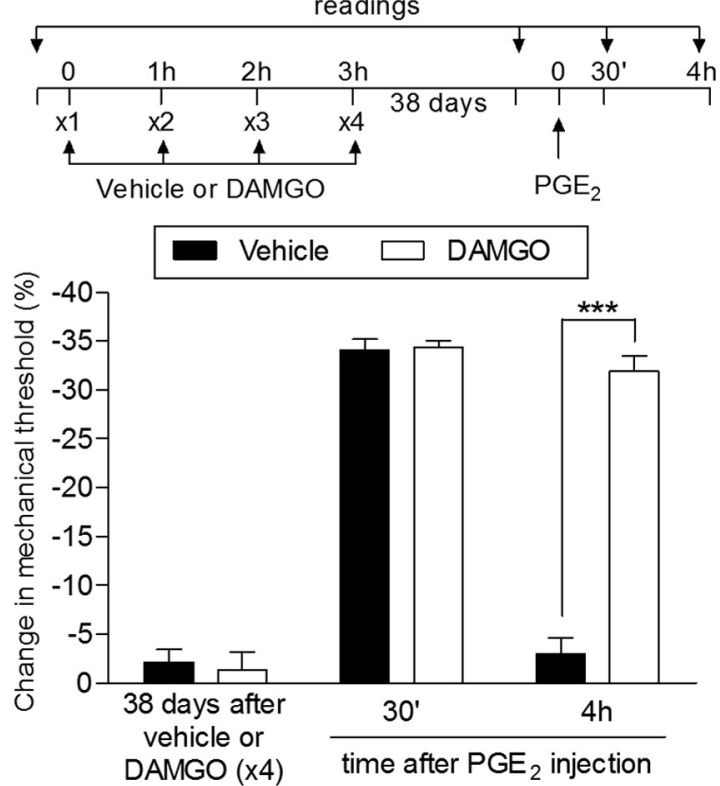

Figure 1. Repeated exposure to DAMG0 induces acute mechanical hyperalgesia and prolongation of $\mathrm{PGE}_{2}$ hyperalgesia in male rats. $A$, Male rats received repeated (hourly, $\times 4$ ) intradermal injections of vehicle (control, black bars) or DAMGO ( $1 \mu \mathrm{g}$, white bars) on the dorsum of the hindpaw and the mechanical nociceptive threshold was evaluated at the injection site 30 min after the first, third, and fourth administration by the Randall-Sellitto paw-withdrawal test. Significant hyperalgesia was observed after a fourth injection of DAMG0, but not to DAMG0 in the vehicle-treated paws $\left(F_{(1,20)}=18.72 ;{ }^{* * *} p<0.001\right.$, when both groups are compared; two-way repeated-measures ANOVA followed by Bonferroni post hoc test); $\boldsymbol{B}$, A separate group of rats received repeated (hourly, $\times 3)$ intradermal injection of DAMGO $(1 \mu \mathrm{g})$ on the dorsum of the hindpaw. A fourth injection $1 \mathrm{~h}$ after the third dose of DAMG0, vehicle (gray bars), or PGE 2 (100 ng, white bars) was performed at the same site and the mechanical nociceptive threshold was evaluated $30 \mathrm{~min}$ and $4 \mathrm{~h}$ later. We observed that, whereas injection of vehicle did not induce significant change in the mechanical threshold, the injection of $\mathrm{PGE}_{2}$ induced hyperalgesia that was still present at the fourth hour $\left(F_{(1,20)}=280.56\right.$; ${ }^{* * *} p<0.0001$, when both groups are compared; two-way repeated-measures ANOVA followed by Bonferroni post hoc test), indicating the presence of priming; $C$, Rats that were treated with 4 injections of vehicle (black bars) or DAMGO (white bars) 1 week before received $\mathrm{PGE}_{2}(100 \mathrm{ng})$ injected at the same site. Mechanical nociceptive threshold was then evaluated $30 \mathrm{~min}$ and $4 \mathrm{~h}$ later. By the time that $P \mathrm{PE}_{2}$ was injected, the mechanical nociceptive thresholds were not different from preinjection control baseline $t_{(5)}=0.6956 ; p=0.5177$, for the vehicle group; $t_{(5)}=1.320 ; p=0.2441$, for the DAMG0 group; paired Student's $t$ test). In both groups, $\mathrm{PGE}_{2}$ induced significant hyperalgesia. However, whereas in the vehicle-treated group, the effect of $\mathrm{PGE}_{2}$ was no longer present at $4 \mathrm{~h}$, in the group previously treated with DAMGO (hourly, $\times 3$ ), the hyperalgesia induced by $\mathrm{PGE}_{2}$ was still present, indicating the presence of priming $\left({ }^{* * *} p<0.0001\right.$ when both groups are compared at the fourth hour, two-way repeated-measures ANOVA followed by Bonferroni post hoc test). $\boldsymbol{D}$. Thirty-eight days after the vehicle $(X 3)$ or DAMGO $(\times 3)$ treatments (no difference in the average mechanical nociceptive thresholds from pretreatments levels was observed: $p=0.0706$ for the vehicle, $t_{(5)}=2.291 ; p=0.1613$ for the DAMG0 group, $t_{(5)}=1.643$; paired Student's $t$ test), PGE 2 was injected again at the same site. We observed that it produced prolonged hyperalgesia in the group previously treated with DAMGO $(\times 3)$, but not in the vehicle-treated control group, and this was significant $4 \mathrm{~h}$ after injection ${ }^{* * * *} p<0.0001$, when both groups are compared, two-way repeated-measures ANOVA followed by Bonferroni post hoc test), indicating that the repeated injection of DAMGO produced long-term plastic changes in nociceptors. $n=6$ paws per group. 
A

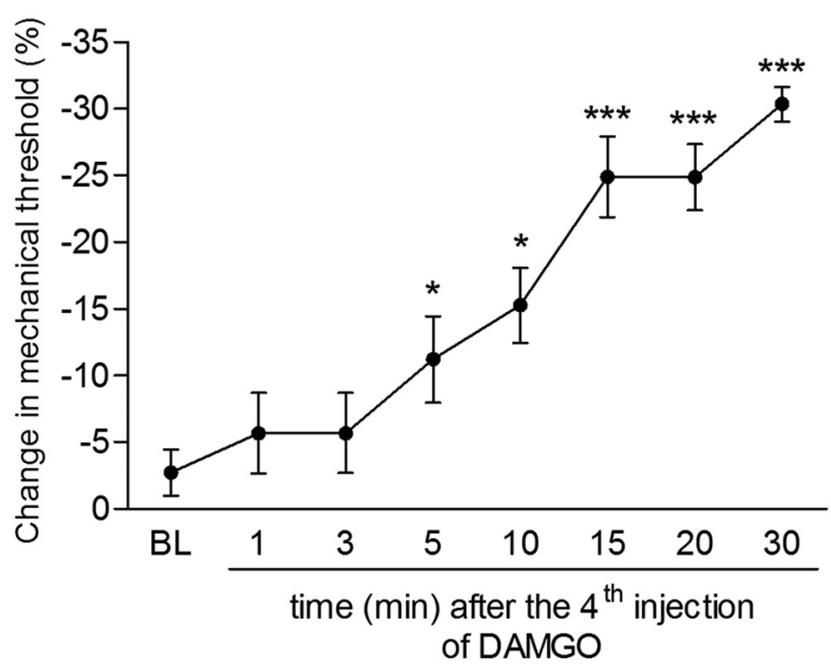

B
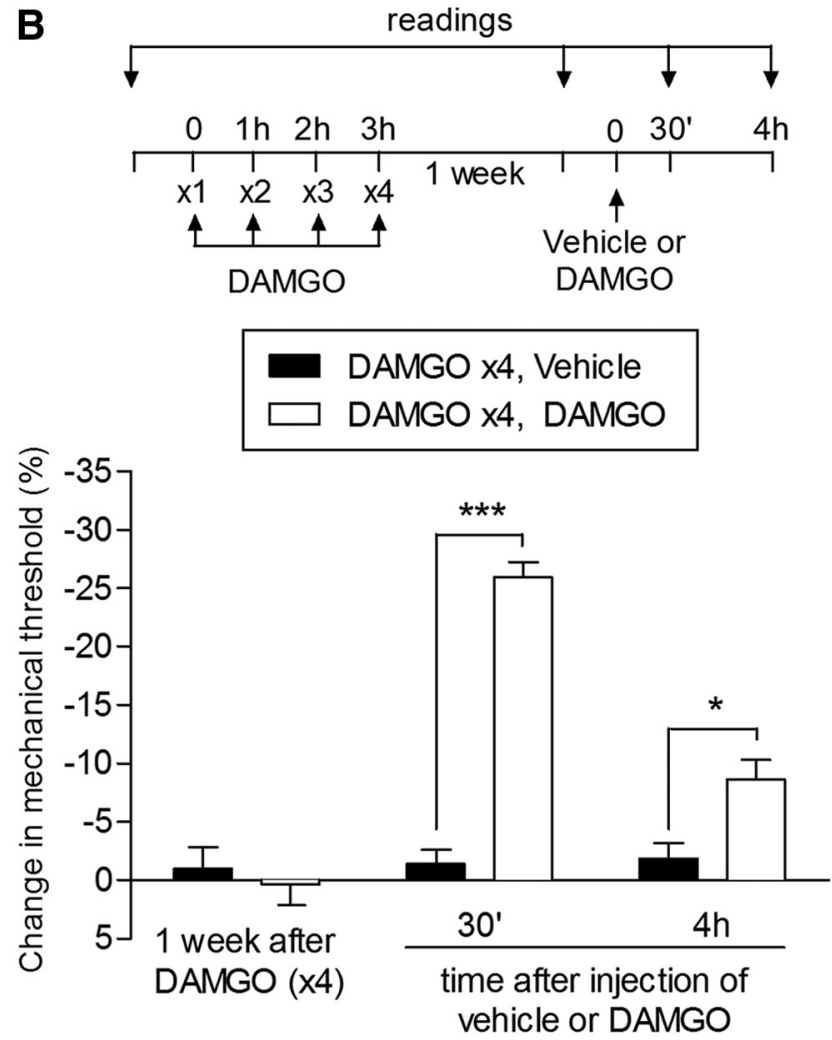

Figure 2. Rapid onset of DAMGO hyperalgesia and long-term persistence oftypell priming. $A$, Mechanical nociceptive threshold was evaluated 1,3,5, 10, 15,20, and 30 min after a fourth injection of DAMGO (1 $\mu \mathrm{g}$ ) on the dorsum of the hindpaw. Significant hyperalgesia was already observed $5 \mathrm{~min}$ after the fourth injection $\left({ }^{*} p<0.05\right.$ and ${ }^{* * *} p<0.005$, compared with thebaseline(BL), pairedStudent'sttest). B, Ratsthat were treated with repeated injection of DAMGO $(1 \mu \mathrm{g} / \mathrm{h} \times 4) 1$ week before received, at the same site, an injection of DAMGO $(1 \mu \mathrm{g}$, white bars) orvehicle (blackbars). Mechanical hyperalgesia, evaluated 30 min and $4 \mathrm{~h}$ after injection, was observed only in the paws previously treated with repeated injection of DAMGO, showing the persistence of the changes in the nociceptor produced by the repeated stimulation of the MOR $\left(F_{(1,20)}=88.69 ; * * * 0<0.001\right.$ and ${ }^{*} p<0.005$, two-way repeated-measures ANOVA followed by Bonferroni posthoctest $n=6$ paws per group).

nociceptor occurring in IB4- ${ }^{-}$nociceptors and, in female as well as male rats. Therefore, whereas a similar phenotype (increased response to $\mathrm{PGE}_{2}$ ) is observed in this model of change in nociceptor function, because it involves distinct mechanisms, we designate it as type II hyperalgesic priming.
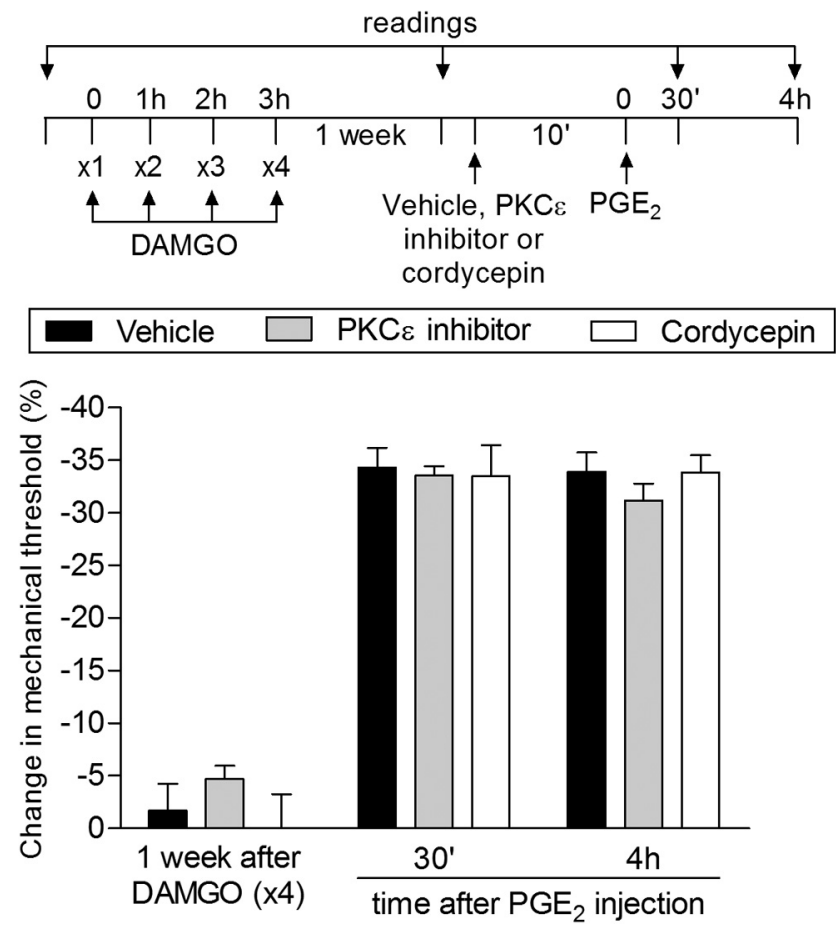

Figure 3. Type II priming is not dependent on $\mathrm{PKC} \varepsilon$ or local protein translation. Male rats that were treated with repeated intradermal administration of DAMG0 $(1 \mu \mathrm{g} / \mathrm{h} \times 4)$ on the dorsum of the hindpaw received 1 week later an injection of $\mathrm{PGE}_{2}(100 \mathrm{ng})$ at the same site in the presence of vehicle (control, black bars), PKC $\varepsilon$ inhibitor ( $1 \mu \mathrm{g}$, gray bars), or the inhibitor of protein translation cordycepin (1 $\mu \mathrm{g}$, white bars) administered $10 \mathrm{~min}$ before. Mechanical nociceptive threshold was evaluated $30 \mathrm{~min}$ and $4 \mathrm{~h}$ after $\mathrm{PGE}_{2}$. We observed no difference between the groups in the prolongation of the $\mathrm{PGE}_{2}$-induced hyperalgesia $\left(F_{(4,30)}=0.72 ; p=\right.$ 0.5861, two-way repeated-measures ANOVA followed by Bonferroni post hoc test), indicating that the neuroplasticity induced by previous repeated injection of DAMGO is not dependent on $\operatorname{PKC} \varepsilon$ or local protein translation. $n=6$ paws per group.

\section{Materials and Methods}

Animals. Experiments were performed on 230-280 g adult male and female Sprague Dawley rats (Charles River Laboratories). Animals were housed in a controlled environment at the animal care facility of the University of California-San Francisco (UCSF), under a $12 \mathrm{~h}$ light/dark cycle. Food and water were available ad libitum. Experiments were approved by the Institutional Animal Care and Use Committee at UCSF and adhered to guidelines of the American Association of Laboratory Animal Care, the National Institutes of Health, and the Committee for Research and Ethical Issues of the International Association for the Study of Pain. In the design of the experiments, effort was made to minimize the number of animals used and their suffering.

Mechanical nociceptive threshold testing. Mechanical nociceptive threshold was quantified using an Ugo Basile Analgesymeter (Randall-Selitto paw-withdrawal test; Stoelting), which applies a linearly increasing mechanical force to the dorsum of the rat's hindpaw, as described previously (Taiwo and Levine, 1989; Taiwo et al., 1989; Ferrari and Levine, 2015). The nociceptive threshold was defined as the force in grams at which the rat withdrew its paw; baseline pawpressure threshold was defined as the mean of the three readings taken just before a test agent was injected. Each paw was treated as an independent measure and each experiment was performed on a separate group of rats. Data are presented as the mean change from baseline mechanical nociceptive threshold.

Drugs and their administration. The chemicals used in this study were as follows: cordycepin 5' -triphosphate sodium salt (protein translation inhibitor), Quin 2 potassium salt hydrate (a calcium chelator), $\mathrm{PGE}_{2}$ (a hyperalgesic agent that sensitizes nociceptors directly), [D-Ala ${ }^{2}, \mathrm{~N}-\mathrm{Me}-$ $\mathrm{Phe}^{4}, \mathrm{Gly}^{5}$-ol]-enkephalin acetate salt (DAMGO, a MOR agonist); mastoparan (a G-protein activator via $\mathrm{G} \alpha_{\mathrm{i}}$ and $\mathrm{G} \alpha_{\mathrm{o}}$ stimulation), SU6656 
A
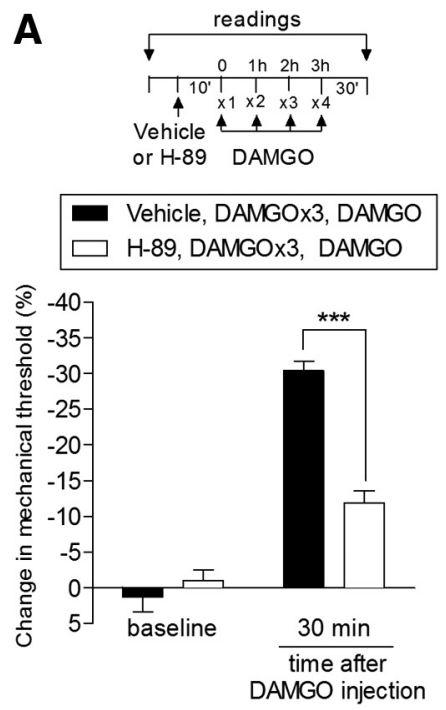

B
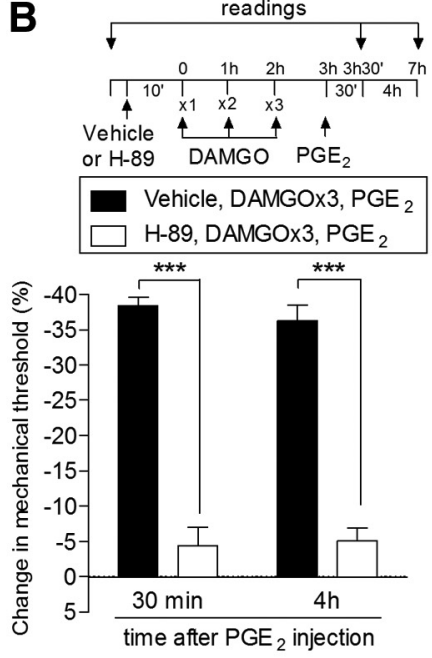
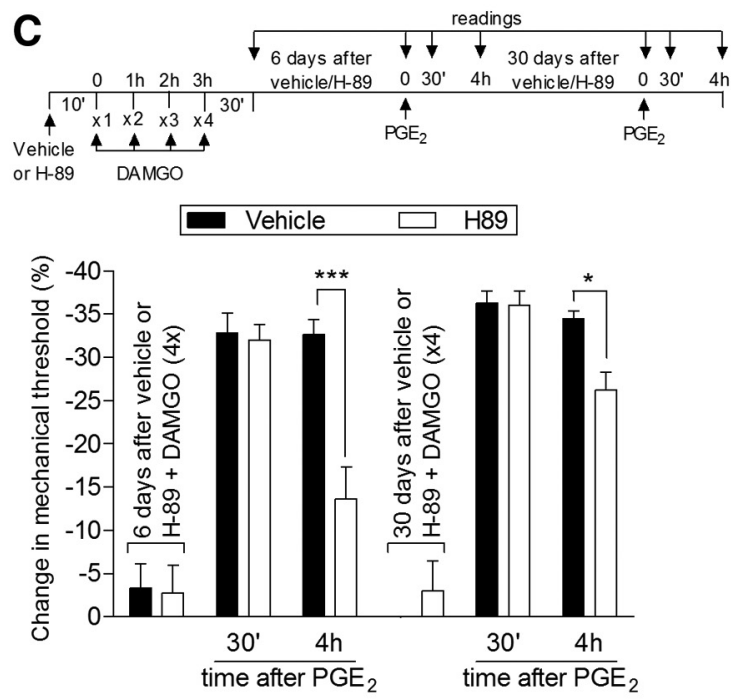

D
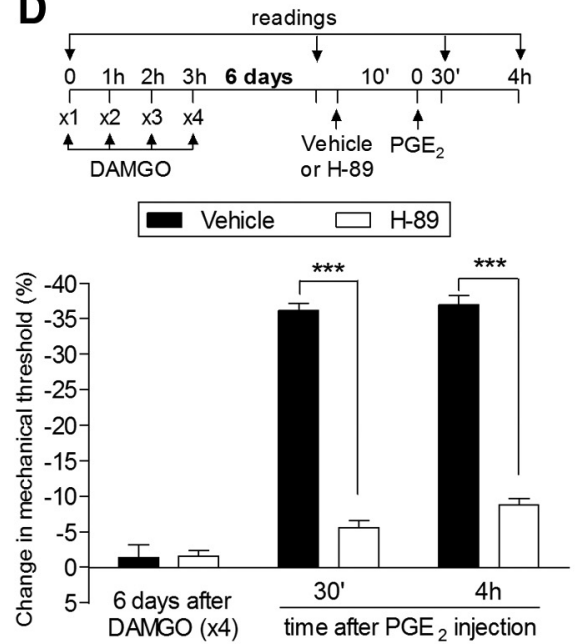

$\mathbf{E}$
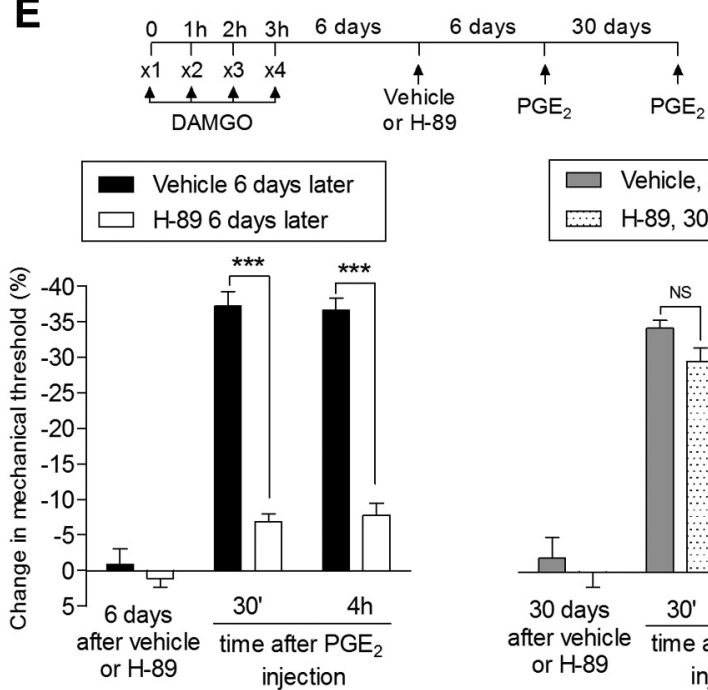

$\square$ Vehicle, 30 days later $\mathrm{H}-89,30$ days later

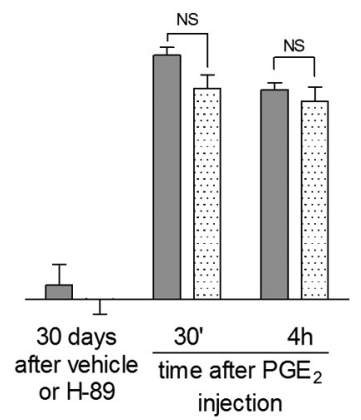

Figure 4. Role of PKA in type ll priming. A, Rats were treated with intradermal injection of vehicle (control, black bars) or H- $89(1 \mu \mathrm{g}$, white bars) on the dorsum of the hindpaw. Ten minutes later, 4 injections of DAMGO ( $1 \mu \mathrm{g}$, hourly) were performed in both groups of rats. We observed, in the group pretreated with $\mathrm{H}-89$, significant attenuation of the mechanical hyperalgesia induced by the fourth injection of DAMGO compared with the control group $\left(F_{(1,10)}=18.52 ;{ }^{* * *} p=0.0016\right.$, two-way repeated-measures ANOVA followed by Bonferroni post hoc test); $\boldsymbol{B}$, Rats were treated with intradermal injection of vehicle or $\mathrm{H}-89(1 \mu \mathrm{g})$ on the dorsum of the hindpaw. Ten minutes later, 3 injections of DAMGO $(1 \mu \mathrm{g} / \mathrm{h} \times 3)$ were performed. One hour after the third injection of DAMG0, $\mathrm{PGE}_{2}(100 \mathrm{ng}$ ) was injected at the same site and the mechanical hyperalgesia was evaluated $30 \mathrm{~min}$ and $4 \mathrm{~h}$ later. Both at $30 \mathrm{~min}$ and $4 \mathrm{~h}$, significant attenuation (Figure legend continues.) 
(an Src inhibitor), U-73122 (an inhibitor of phospholipase $\mathrm{C} \gamma$ ), wortmannin (a PI3K inhibitor), Z-VAD-FMK (a caspase inhibitor), and pertussis toxin ( $\mathrm{a} \mathrm{G}_{\mathrm{i}}$-protein inhibitor) (all from Sigma-Aldrich); H-89 dihydrochloride (an inhibitor of PKA) and gallein (an inhibitor of G-protein $\beta / \gamma$ ) (both from Santa Cruz Biotechnology); G-Protein $\beta \gamma$ Binding Peptide (a G-protein $\beta / \gamma$ activator) and $\mathrm{PKC} \mathrm{V}_{1-2}$ (PKC $\varepsilon$-I, a PKC $\varepsilon$-specific translocation inhibitor peptide (Johnson et al., 1996; Khasar et al., 1999) (both from Calbiochem); and NGmonomethyl-L-arginine acetate (L-NMMA, an inhibitor of nitric oxide synthase) and the potent cell-permeable cAMP analog 8-bromo cAMP (both from Tocris Bioscience).

The selection of the doses used was based on previous studies showing their effectiveness when injected intradermally on the dorsum of the rat hindpaw (Taiwo et al., 1989; Taiwo and Levine, 1991; Aley and Levine, 1997b; Aley et al., 2001; Dina et al., 2009; Joseph and Levine, 2010b; Ferrari et al., 2012). The stock solution of $\mathrm{PGE}_{2}(1 \mu \mathrm{g} / \mu \mathrm{l})$ was prepared in $10 \%$ ethanol and additional dilutions made with physiological saline $(0.9 \% \mathrm{NaCl})$, yielding a final ethanol concentration of $<1 \%$. DAMGO, cordycepin, 8-bromo cAMP, and pertussis toxin were dissolved in saline. All other drugs were dissolved in $100 \%$ DMSO (SigmaAldrich) and further diluted in saline containing 2\% Tween 80 (Sigma-Aldrich). The final concentration of DMSO and Tween 80 was $\sim 2 \%$. All drugs were administered intradermally on the dorsum of the hindpaw in a volume of $5 \mu$ l using a 30-gauge hypodermic needle adapted to a $50 \mu \mathrm{l}$ Hamilton syringe. The administration of all drugs, except $\mathrm{PGE}_{2}$,

\section{$\leftarrow$}

(Figure legend continued.) of the mechanical hyperalgesia induced by $\mathrm{PGE}_{2}$ was observed in the group pretreated with $\mathrm{H}-89\left(F_{(1,10)}=189.86,{ }^{* * *} p<0.0001\right.$, vehicle vs $\mathrm{H}-89$ groups; two-way repeated-measures ANOVA followed by Bonferroni post hoc test); $C$, Six days later, a time point when the mechanical nociceptive threshold was not different from the pretreatment levels $\left(t_{(5)}=2.000 ; p=0.1019\right.$, for the control group; $t_{(5)}=2.169 ; p=0.0822$, for the H-89 group; paired Student's $t$ test), $\mathrm{PGE}_{2}(100 \mathrm{ng})$ was injected at the same site and the mechanical hyperalgesia was evaluated $30 \mathrm{~min}$ and $4 \mathrm{~h}$ later. Although $\mathrm{PGE}_{2}$-induced hyperalgesia was present 30 min after injection, in the group previously treated with $\mathrm{H}-89$, it was significantly reduced at the fourth hour $\left(F_{(1,20)}=15.67,{ }^{* * * *} p<0.001\right.$, when both groups are compared at the fourth hour; two-way repeated-measures ANOVA followed by Bonferroni post hoc test). To determine whether type II priming was permanently prevented by $\mathrm{H}-89, \mathrm{PGE}_{2}$ was injected again at the same site $30 \mathrm{~d}$ later. At this time, we observed that the hyperalgesia induced by $\mathrm{PGE}_{2}$ was prolonged in both groups; $\boldsymbol{D}$, Rats received repeated (hourly, $\times 4$ ) intradermal injection of DAMGO $(1 \mu \mathrm{g})$ on the dorsum of the hindpaw. Six days later, when the mechanical thresholds were no longer different from pre-DAMGO levels $\left(t_{7}=0.7593 ; p=0.4819\right.$, paired Student's $t$ test), vehicle (control, black bars) or $\mathrm{H}-89(1 \mu \mathrm{g}$, white bars) was injected at the same site, followed 10 min later by $\mathrm{PGE}_{2}(100 \mathrm{ng})$. Although $\mathrm{PGE}_{2}$-induced hyperalgesia was still present $4 \mathrm{~h}$ later in the group that received vehicle, in the group treated with $\mathrm{H}-89$, it was attenuated at both time points $\left(F_{(1,28)}=585.86^{* * *} p<0.0001\right.$, two-way repeated-measures ANOVA followed by Bonferroni post hoc test). $\boldsymbol{E}$, Left, Six days later, when PGE 2 was injected again at the same site, the mechanical hyperalgesia in the group that had previously received $\mathrm{H}-89$ ( $6 \mathrm{~d}$ before, white bars) was still significantly attenuated at both 30 min and $4 \mathrm{~h}\left(F_{(2,18)}=\right.$ $133.63,{ }^{* * *} p<0.0001, \mathrm{H}-89$ vs control groups, two-way repeated-measures ANOVA followed by Bonferroni post hoc test). Right, To determine whether the treatment with $\mathrm{H}-89$ had permanently reversed the type II priming, $\mathrm{PGE}_{2}$ was again injected at the same site $30 \mathrm{~d}$ later (gray bars). In this case, however, we observed that $\mathrm{PGE}_{2}$ produced significant hyperalgesia that was present 30 min and $4 \mathrm{~h}$ after injection in both groups, indicating that type II priming was present. $n=6$ paws per group.
DAMGO, and 8-bromo cAMP, was preceded by a hypotonic shock to facilitate cell permeability to these agents $(2 \mu \mathrm{l}$ of distilled water separated by a bubble of air to avoid mixing in the same syringe) to facilitate the entry of compounds into the nerve terminal (Borle and Snowdowne, 1982; Burch and Axelrod, 1987).

Intrathecal administration of IB4-saporin. IB4-saporin, a neurotoxin for the IB4 ${ }^{+}$nociceptor (Advanced Targeting Systems), was diluted with saline and a dose of $3.2 \mu \mathrm{g}$ in a volume of $20 \mu \mathrm{l}$ was administered intrathecally $10 \mathrm{~d}$ before priming experiments. This dose of IB4-saporin and the time point chosen for evaluation of its effect was based in previous reports from us and others (Vulchanova et al., 2001; Joseph et al., 2008; Joseph and Levine, 2010a; Nishiguchi et al., 2004). Rats were briefly anesthetized with 2.5\% isoflurane (Phoenix Pharmaceuticals) in $97.5 \%$ $\mathrm{O}_{2}$. Then, a 30-gauge hypodermic needle was inserted on the midline into the subarachnoid space between the L4 and L5 vertebrae. The control treatment consisted of intrathecal injection of saline $(20 \mu \mathrm{l})$. Animals regained consciousness $\sim 1 \mathrm{~min}$ after removal from the anesthetic chamber. There was no effect of IB4-saporin on the mechanical nociceptive threshold per se.

Oligodeoxynucleotide antisense to PLC- $\beta 3$. The oligodeoxynucleotide (ODN) antisense (AS) sequence for PLC- $\beta 3$ was directed against a unique region of the rat PLC- $\beta 3$ mRNA sequence (GenBank accession number NM_033350). The AS-ODN sequence was 5'-CCTTCAAGACCTCACCCT AC- $3^{\prime}$ and the ODN mismatch sequence (MM-ODN) was designed by mismatching 8 bases (denoted by bold face) of the PLC- $\beta 3$ AS-ODN sequence, $5^{\prime}$-GGTTGAAGAGGTCACGCAAG-3' (Joseph et al., 2007). We have shown previously that spinal intrathecal administration of AS-ODN with this sequence decreases PLC- $\beta 3$ protein in dorsal root ganglia (Joseph et al., 2007).

Before use, ODNs were lyophilized and reconstituted in $0.9 \% \mathrm{NaCl}$ to a concentration of $2 \mu \mathrm{g} / \mu \mathrm{l}$. During each injection, rats were briefly anesthetized with $2.5 \%$ isoflurane in $95 \% \mathrm{O}_{2}$. A 30 -gauge hypodermic needle 


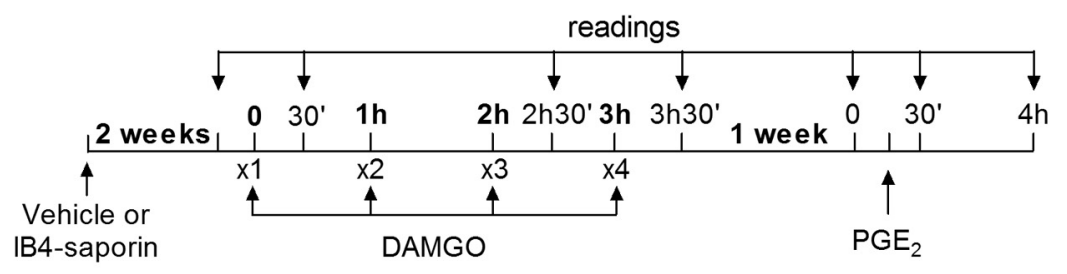

Vehicle, DAMGO x4 $\square$ IB4-saporin, DAMGO x4
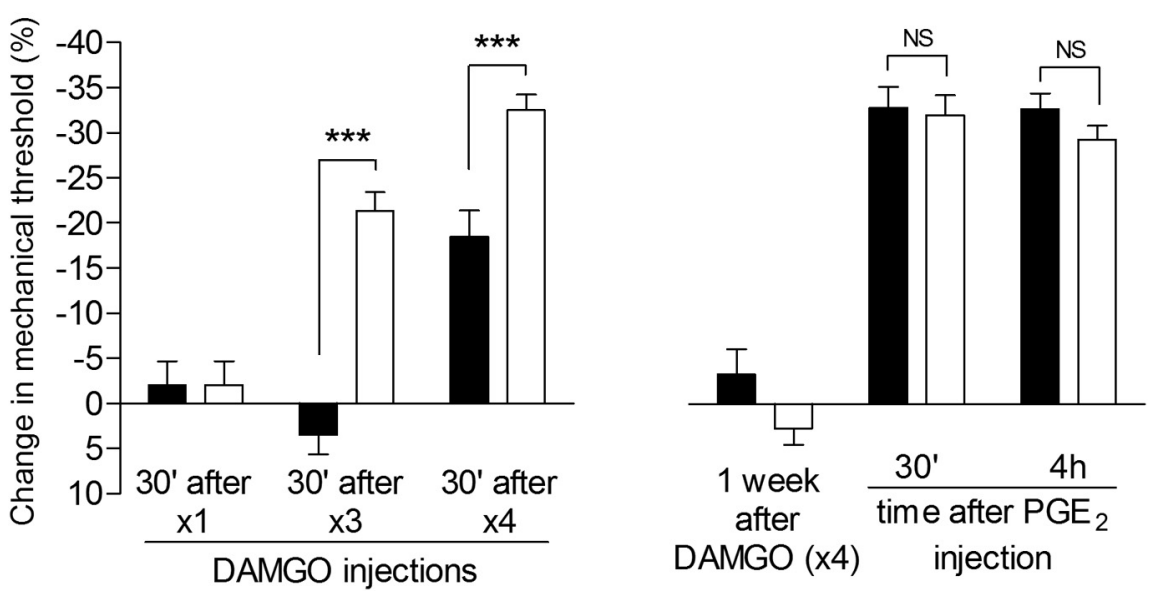

Figure 6. Effect of elimination of IB4 ${ }^{+}$nociceptors on type II priming. Left, Male rats were treated with vehicle (control, black bars) or IB4-saporin (3.2 $\mu \mathrm{g} / 20 \mu \mathrm{l}$; white bars) by intrathecal injection. Two weeks later, DAMGO (1 $\mu \mathrm{g})$ was injected (hourly, $\times 4)$ on the dorsum of the hindpaw. Although, in the vehicle-treated group, the mechanical hyperalgesia developed after the fourth injection of DAMGO, in the IB4-saporin-treated group, it was already present after the third injection, significantly further increasing after the fourth injection $\left(F_{(1,20)}=33.11 ;{ }^{* * *} p<0.001\right.$, when both groups are compared; two-way repeatedmeasures ANOVA followed by Bonferroni post hoc test). Right, One week later, when the mechanical thresholds were not different from the pre-DAMGO baseline $\left(t_{(5)}=0.9035 ; p=0.4077\right.$, for the control group; $t_{(5)}=1.419 ; p=0.2150$, for the IB4-saporin group, paired Student's $t$ test), PGE $_{2}(100 \mathrm{ng})$ was injected at the same site on the dorsum of the hindpaw and the mechanical hyperalgesia was evaluated $30 \mathrm{~min}$ and $4 \mathrm{~h}$ later. Two-way repeated-measures ANOVA followed by Bonferroni post hoc test showed PGE 2 -induced hyperalgesia at $30 \mathrm{~min}$, which was still present at the fourth hour after injection in both groups, with no significant (NS) difference between the groups ( $p>0.05$, two-way repeated-measures ANOVA followed by Bonferroni post hoc test). These data support the suggestion that IB4 ${ }^{+}$nociceptors do not contribute to the prolonged hyperalgesia induced by $\mathrm{PGE}_{2}$ observed in type Il priming. $n=6$ paws per group.

was then inserted on the midline into the subarachnoid space between the L4 and L5 vertebrae. A total of $40 \mu \mathrm{g}$ of ODN, in a volume of $20 \mu \mathrm{l}$, was slowly injected. The intrathecal site of injection was confirmed by a sudden tail flick, a reflex that is evoked by subarachnoid space access and bolus injection (Mestre et al., 1994). Animals regained consciousness $\sim 1$ min after the injection. The use of antisense to manipulate the expression of proteins in nociceptors, important for their role in nociceptor sensitization, is well supported by previous studies by others (Song et al., 2009; Su et al., 2011; Quanhong et al., 2012; Sun et al., 2013), as well as our group (Parada et al., 2003a; Ferrari et al., 2010; Bogen et al., 2012; Ferrari et al., 2012).

$D A M G O$-induced changes in nociceptor function. We have shown previously that, whereas a single injection of the selective MOR agonist DAMGO alone has no effect on nociceptive threshold and attenuates the mechanical hyperalgesia induced by PGE $_{2}$ (Levine and Taiwo, 1989; Taiwo and Levine, 1990), when injected repeatedly, it produces changes in nociceptor function such as tolerance, no longer producing an antihyperalgesic effect and producing mechanical hyperalgesia by itself (Aley et al., 1995; Aley and Levine, 1997a). The repeated injection of DAMGO also induces a latent state of hyperresponsiveness to subsequent injection of proalgesic mediators (Joseph et al., 2010), here referred to as type II hyperalgesic priming. Similar to the classical, type I, hyperalgesic priming (Aley et al., 2000; Reichling and Levine, 2009; Ferrari et al., 2014), this model of neuroplasticity is expressed as prolongation of the mechanical hyperalgesia produced by $\mathrm{PGE}_{2}$, lasting at least $4 \mathrm{~h}$, as opposed to the injection of $\mathrm{PGE}_{2}$ in naive paws, in which hyperalgesia dissipated by $2 \mathrm{~h}$
(Aley and Levine, 1999). To study the mechanism involved in the hyperalgesia produced by the repeated activation of the MOR, 3 hourly intradermal injections of DAMGO $(1 \mu \mathrm{g})$ were performed on the dorsum of the hindpaw; mechanical hyperalgesia was observed starting after a fourth injection of DAMGO (see Fig. 1). To investigate the changes in nociceptor function produced by previous repeated injection of DAMGO — measured as prolonged response to a hyperalgesic mediator at a point in time when the mechanical nociceptive threshold was not different from pre-DAMGO baseline levels- $-\mathrm{PGE}_{2}(100 \mathrm{ng})$ was injected at the same site and hyperalgesia was evaluated after 30 min and again at $4 \mathrm{~h}$. The presence of hyperalgesia at the fourth hour is characteristic of priming (Aley et al., 2000; Ferrari et al., 2014). To differentiate the intracellular signaling pathways that play a role in type I and type II priming and to investigate the mechanisms that play a role in the induction of the changes in nociceptor function produced by the repeated activation of the MOR, pharmacological agents were injected before DAMGO (prevention protocol). To investigate the second messengers involved in the expression of the neuroplasticity, the inhibitors were administered before the injection of $\mathrm{PGE}_{2}$ in the primed paw (inhibition protocol). To evaluate the role of messengers in the maintenance of the neuroplasticity, $\mathrm{PGE}_{2}$ was injected again at a time point when the inhibitors were no longer present (reversal protocol).

Statistics. In all experiments, the dependent variable was paw-withdrawal threshold, expressed as percentage change from baseline. The average paw-withdrawal threshold before the three injections of DAMGO (initial baseline mechanical nociceptive threshold) and before the subsequent injection of DAMGO (a fourth injection or injection 1 week later; see Fig. 2B), $\mathrm{PGE}_{2}$ (varying from $1 \mathrm{~h}$ to $38 \mathrm{~d}$ after 3 hourly injections of DAMGO, depending on the experiment), or 8-bromo cAMP ( $1 \mathrm{~h}$ after 3 injections of DAMGO; see Fig. 12) were $120.0 \pm 0.5 \mathrm{~g}$ and $118.8 \pm 0.8 \mathrm{~g}$, respectively; paired Student's $t$ test showed no significant difference between these values $\left(t_{(317)}=1.156, p=0.2505\right)$, indicating that the induction of type II priming by DAMGO does not affect the mechanical threshold. The total number of rats used in this study was 159 (318 paws). To compare the percentage change in the hyperalgesia induced by repeated injections of the neuroplasticity inducer (DAMGO, or activators of G-protein subunits, e.g., mastoparan and G-Protein $\beta \gamma$ Binding Peptide), a one-way or two-way repeated-measures ANOVA, followed by Bonferroni post test, was performed to compare the effect of $\mathrm{PGE}_{2}$ in different groups in the presence or absence of inhibitors. GraphPad Prism 5.0 software was used to plot graphs and to perform the statistical analyses. $p<0.05$ was considered statistically significant. Data are presented as mean \pm SEM.

\section{Results}

Distinguishing a novel type of hyperalgesic priming

Although 3 hourly intradermal injections of the highly selective MOR agonist DAMGO $(1 \mu \mathrm{g})$ had no effect on nociceptive threshold (Aley et al., 1995; Aley and Levine, 1997a), injection of a fourth dose $1 \mathrm{~h}$ later induced mechanical hyperalgesia (Fig. 1A). In addition, injection of the pronociceptive inflammatory mediator $\mathrm{PGE}_{2}(100 \mathrm{ng}) 1 \mathrm{~h}$ after rats had been treated with 3 injections of DAMGO induced markedly prolonged mechanical 
A
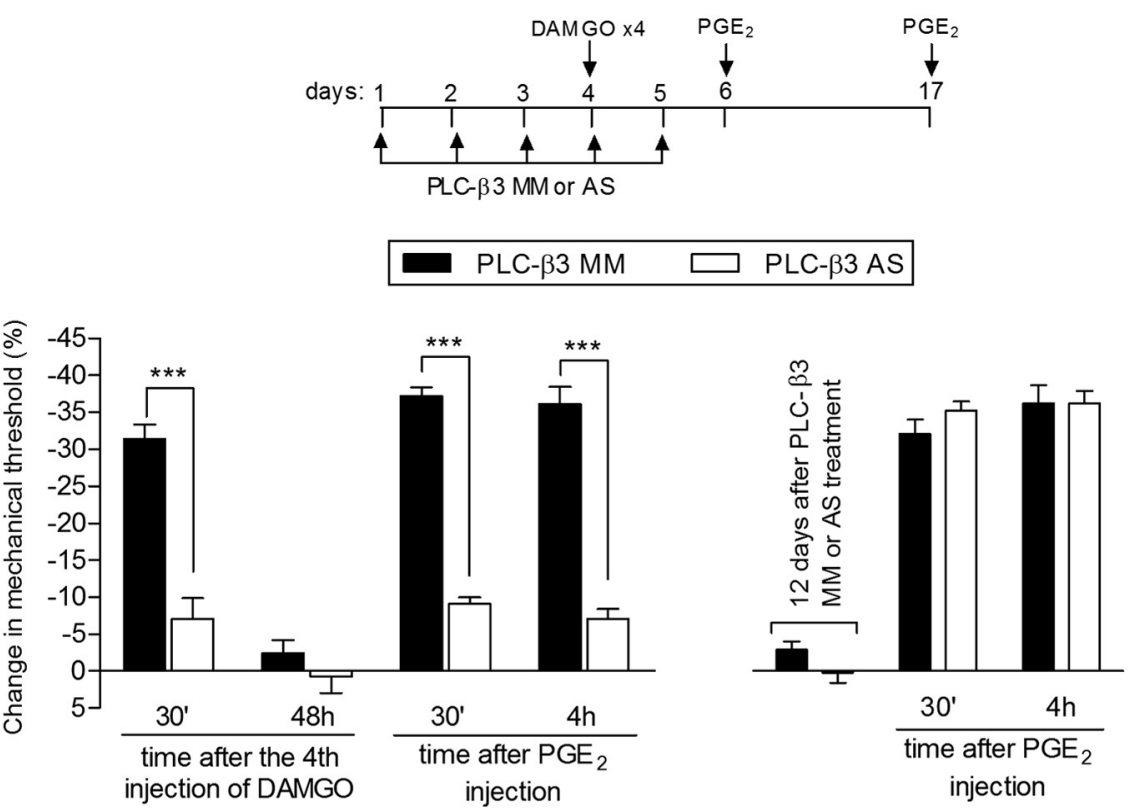

B
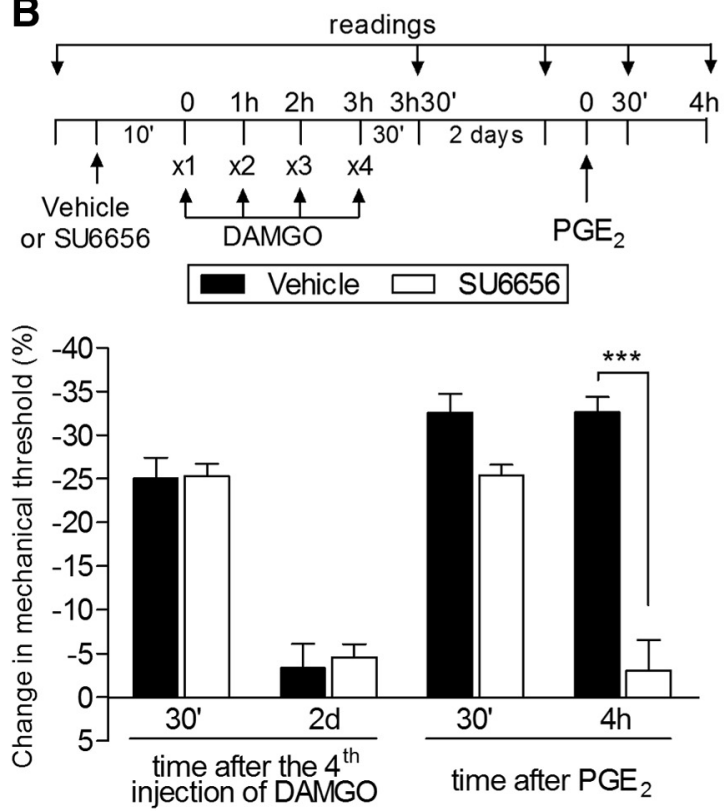

C

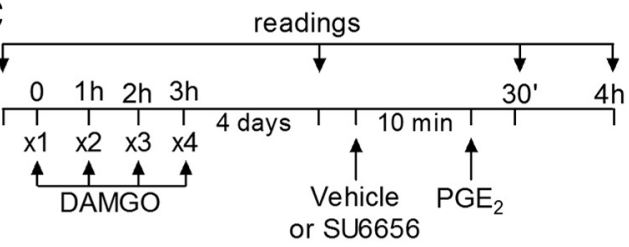

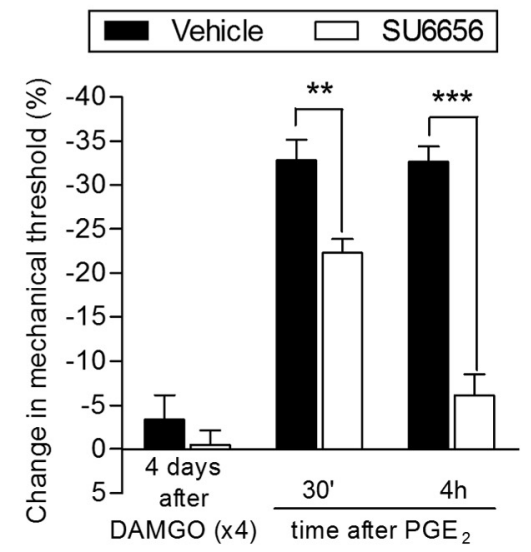

Figure 7. Second messengers involved in type II priming: PLC- $\beta 3$ and Src. A, Left, Rats were treated with daily spinal intrathecal injections of MM-ODN (black bars) or AS-ODN (white bars) for PLC $\beta 3$ mRNA for 3 consecutive days. On the fourth day, repeated (hourly, $\times 4)$ intradermal injections of DAMGO $(1 \mu \mathrm{g})$ on the dorsum of the hindpaw were performed and the mechanical nociceptive threshold was evaluated 30 min after the fourth DAMGO injection. We observed that, in the MM-ODN-treated group, but not in the AS-ODN-treated group, the fourth injection of DAMGO produced significant mechanical hyperalgesia ( ${ }^{* * *} p=0.0009$, paired Student's $t$ test, when both groups are compared), suggesting a role for PLC- $\beta 3$ in DAMG0 hyperalgesia. 0DN treatment continued for 2 more days and, at a time point when the mechanical thresholds were not different from the pre-DAMGO levels $\left(t_{(5)}=0.9918 ; p=0.3668\right.$, for the MM-0DN group; $t_{(5)}=2.490 ; p=$ 0.0551 , for the AS-ODN group; paired Student's $t$ test), PGE $(100 \mathrm{ng})$ was administered in both groups. Evaluation of the mechanical thresholds 30 min and $4 \mathrm{~h}$ after injection showed that, whereas PGE 2 induced hyperalgesia that was still present $4 \mathrm{~h}$ later in the group treated with MM-ODN, in the group treated with AS-ODN against PLC- $\beta 3$, the hyperalgesia was significantly attenuated at both time points $\left(F_{(1,20)}=128.33 ;{ }^{* * *} p<0.0001\right.$, two-way repeated-measures ANOVA followed by Bonferroni post hoc test). Right, To determine whether the reversal of type II priming by treatment with AS-ODN was permanent, $\mathrm{PGE}_{2}$ was injected again in the same site $12 \mathrm{~d}$ after the last ODN injection. We observed that $\mathrm{PGE}_{2}$-induced mechanical hyperalgesia was still present at the fourth hour, indicating the presence of type II priming. B. Rats were treated with intradermal injection of vehicle (control, black bars) or SU6656 (1 $\mu \mathrm{g}$, white bars). Ten minutes later, repeated injections of DAMGO $(1 \mu \mathrm{g})$ were performed on the dorsum of the hindpaw. No difference in the mechanical hyperalgesia after the fourth injection of DAMGO was observed when the groups treated with $\mathrm{SU} 6656$ or vehicle were compared (nonsignificant, NS; paired Student's $t$ test). Two days later, when the mechanical thresholds were not different from pretreatment levels $\left(t_{(5)}=2.5690 ; p=0.0501\right.$, for the control group; $t_{(5)}=0.5423 ; p=0.6109$, for the SU6656 group; paired Student's $t$ test), PGE 2 (100 ng) was injected at the same site and mechanical hyperalgesia was evaluated 30 min and $4 \mathrm{~h}$ later. In the group previously treated with SU6656, PGE -induced hyperalgesia was almost completely inhibited at the fourth hour $\left(F_{(1,20)}=100.00\right.$; ${ }^{* * *} p<0.0001$, when both groups are compared at the $30 \mathrm{~min}$ and fourth hour, respectively; two-way repeated-measures ANOVA followed by Bonferroni posthoc test), indicating a role of Src in type ll priming. $C$, Male rats received repeated (hourly, $\times 4)$ intradermal injections of DAMGO $(1 \mu \mathrm{g})$ on the dorsum of the hindpaw. Four days later, when the mechanical thresholds were not different from the pre-DAMG0 levels $\left(t_{(5)}=0.8500 ; p=\right.$ 0.4341 , for the control group; $t_{(5)}=1.356 ; p=0.2332$, for the SU6656 group; paired Student's $t$ test), vehicle (control) or the Src inhibitor SU6656 (1 $\mu$ g) was injected at the same site, followed 10 min later by $\mathrm{PGE}_{2}(100 \mathrm{ng})$. Although PGE induced significant hyperalgesia that was still present when evaluated $4 \mathrm{~h}$ later in the vehicle-treated group, in the group treated with SU6656, $\mathrm{PGE}_{2}$-induced hyperalgesia was attenuated at the fourth hour $\left(F_{(1,20)}=184.31 ; * * 0.01\right.$ and ${ }^{* * *} p<0.001$, two-way repeated-measures ANOVA followed by Bonferroni post hoc $) . n=6$ paws per group. 

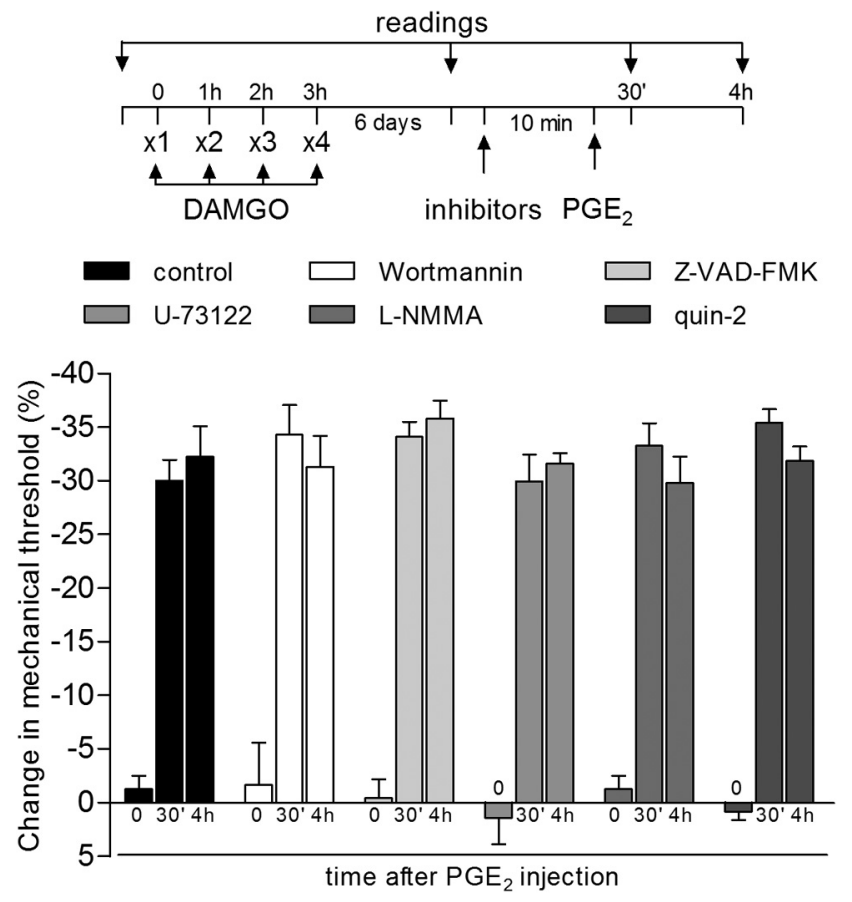

Figure 8. Some second messengers not involved in type II priming. The groups of rats that had been treated with repeated (hourly, $\times 4)$ intradermal injections of DAMGO $(1 \mu \mathrm{g})$ on the dorsum of the hindpaw $6 \mathrm{~d}$ before received, in a dose of $1 \mu \mathrm{g}$ at the same site, injection of vehicle (control, black bars) or of the inhibitors of intracellular messengers wortmannin (PI3K), Z-VAD-FMK (caspase), U-73122 (PLC $\gamma$ ), L-NMMA (nitric oxide synthase), and quin-2 (calcium). Ten minutes later, $\mathrm{PGE}_{2}(100 \mathrm{ng})$ was injected and mechanical hyperalgesia was evaluated 30 min and $4 \mathrm{~h}$ after $\mathrm{PGE}_{2}$. In all groups, we observed that $\mathrm{PGE}_{2}$ induced significant hyperalgesia that was still present when evaluated $4 \mathrm{~h}$ after injection, ruling out the involvement of these second messengers in type II priming. $n=6$ paws per group.

hyperalgesia compared with $\mathrm{PGE}_{2}$-induced hyperalgesia in naive rats (Joseph et al., 2010), still being present $4 \mathrm{~h}$ after administration (Fig. 1B). These results indicate the presence of a plastic change in the nociceptor produced by the repeated injection of DAMGO, an effect that persisted for at least $38 \mathrm{~d}$. When $\mathrm{PGE}_{2}$ was injected at the same site $7 \mathrm{~d}$ (Fig. 1C) and $38 \mathrm{~d}$ (Fig. 1D) after the injection of 4 doses of DAMGO, it produced prolonged hyperalgesia. This marked prolongation of $\mathrm{PGE}_{2}$-induced mechanical hyperalgesia resembles that observed in the setting of hyperalgesic priming induced by activation of PKCe (Aley et al., 2000; Parada et al., 2005; Reichling and Levine, 2009; Joseph and Levine, 2010a; Ferrari and Levine, 2015). However, in contrast to classical hyperalgesic priming, which takes at least $72 \mathrm{~h}$ to develop (Bogen et al., 2012; Ferrari et al., 2015), this neuroplasticity developed much more rapidly, with the onset of the hyperalgesia produced by the fourth injection of DAMGO already significant by $5 \mathrm{~min}$ (Fig. $2 A$ ). In addition, the persistence of the neuroplasticity produced by the initial injections of DAMGO was confirmed by production of hyperalgesia by injection of DAMGO at the same site 1 week later (Fig. $2 B$ ).

To investigate whether the mechanisms underlying the neuroplasticity produced by repeated injection of DAMGO was different from the one observed in classical hyperalgesic priming, we evaluated the effect of inhibitors shown previously to attenuate the prolongation of $\mathrm{PGE}_{2}$-induced hyperalgesia in priming induced by activation of PKC $\varepsilon$ (Aley et al., 2000; Parada et al., 2003a; Ferrari et al., 2013b) in DAMGO-treated animals. We observed that the injection of neither $\mathrm{PKC} \varepsilon_{\mathrm{V} 1-2}(1 \mu \mathrm{g} / \mathrm{i} . \mathrm{d}$.$) , a$ selective $\mathrm{PKC} \varepsilon$ translocation inhibitor (Fig. 3, gray bars), nor cordycepin ( $1 \mu \mathrm{g} / \mathrm{i} . \mathrm{d}$.), a selective protein translation inhibitor, at the same site as $\mathrm{PGE}_{2}$ on the dorsum of the hindpaw (Fig. 3, white bars) affected the prolongation of $\mathrm{PGE}_{2}$-induced hyperalgesia. Therefore, because PKC $\varepsilon$ dependence and ongoing local protein translation, two of the key features of classic - here referred to as type I-hyperalgesic priming (Ferrari et al., 2013b; Ferrari et al., 2014; Ferrari et al., 2015), were not observed in the neuroplasticity produced by repeated injection of DAMGO, we referred to this condition as type II hyperalgesic priming.

Unlike the changes in nociceptor function observed in type I priming (Aley et al., 2000; Parada et al., 2003a; Reichling and Levine, 2009; Ferrari et al., 2014), those induced by repeated administration of DAMGO were inhibited by pretreatment with the selective protein kinase A (Konopka and van Wijhe, 2010) inhibitor H-89 ( $1 \mu \mathrm{g})$ - that is, both DAMGO-induced hyperalgesia (Fig. $4 A$ ) and the prolongation of $\mathrm{PGE}_{2}$-induced hyperalgesia (Fig. $4 B$ ) were attenuated. Interestingly, although we still observed significant attenuation of the prolongation of $\mathrm{PGE}_{2}$ induced hyperalgesia $6 \mathrm{~d}$ after the injection of $\mathrm{H}-89$, when $\mathrm{PGE}_{2}$ was injected $30 \mathrm{~d}$ after $\mathrm{H}-89$, the hyperalgesia observed by the fourth hour was similar in magnitude to that in the control group (Fig. 4C). These findings indicate that the effect of H-89 was reversible over time and that PKA is involved only in the expression, not the induction, of type II priming; that is, a PKAindependent mechanism is involved in the induction of the changes in the nociceptor produced by repeated activation of the MOR. Moreover, injection of $\mathrm{H}-89$ in naive (i.e., nonprimed) rats inhibits the hyperalgesia induced by $\mathrm{PGE}_{2}$ injected $10 \mathrm{~min}$ later, but not when injected $6 \mathrm{~h}$ later (D. Araldi, unpublished observation), indicating that the effect of $\mathrm{H}-89$ lasts no more than a few hours. That PKA has a role in the expression of type II priming was further confirmed when we injected $\mathrm{H}-89$ after the repeated injection of DAMGO; its administration $6 \mathrm{~d}$ after DAMGO inhibited $\mathrm{PGE}_{2}$ hyperalgesia at both $30 \mathrm{~min}$ and $4 \mathrm{~h}$ (inhibition protocol; Fig. $4 D$ ), an effect still observed when $\mathrm{PGE}_{2}$ was injected again $6 \mathrm{~d}$ later (Fig. $4 E$, left). However, injection of $\mathrm{PGE}_{2} 30 \mathrm{~d}$ after $\mathrm{H}-89$ produced prolonged hyperalgesia (Fig. $4 E$, right), demonstrating that the effect of $\mathrm{H}-89$ is reversible and that PKA is involved in the expression, but not the induction or maintenance, of type II priming. We have shown previously that inhibition of PKA did not affect prolongation of $\mathrm{PGE}_{2}$ hyperalgesia associated with type I hyperalgesic priming (Aley et al., 2000). DAMGO-induced, type II priming also differs from type I priming in the following: (1) whereas agonists at cell surface receptors that signal via $\mathrm{PKC} \varepsilon$ only produce priming (type I) in male rats (Joseph et al., 2003), DAMGO induced priming (type II) in female as well as male rats (Fig. 5); and (2) intrathecal administration of IB4-saporin, a neurotoxin for IB4 ${ }^{+}$nociceptors that eliminates type I priming (Joseph and Levine, 2010a), actually increased the DAMGO-induced hyperalgesia (Fig. 6) that was observed already after the third, instead of the fourth, injection of DAMGO.

\section{Intracellular second messengers involved in the expression of type II priming}

We described previously a role of PKA in another type of nociceptor neuroplasticity induced by the transient downregulation of G-protein related kinase 2 (GRK2) induced by intrathecal antisense, which also involves the intracellular second messengers PLC- $\beta 3$ and Src (Ferrari et al., 2012). Therefore, we tested whether the inhibition of PLC- $\beta 3$ and Src would affect the expression of priming induced by repeated injection of DAMGO. Pretreatment with AS-ODN against PLC- $\beta 3$ mRNA inhibited the 
A

\begin{tabular}{|c|c|c|c|c|c|c|c|}
\hline$\downarrow$ & & & & & & & \\
\hline 0 & $30^{\prime}$ & 1h30' & $2 \mathrm{~h} 30^{\prime}$ & $3 \mathrm{~h} 30^{\prime}$ & $4 \mathrm{~h}$ & $0 \quad 30^{\prime}$ & \\
\hline$T$ & I & 1 & $\mid$ & 1 & 4 davs & 10 & \\
\hline$\uparrow$ & $\mathrm{x} 1$ & $\times 2$ & $\times 3$ & $x 4$ & & 4 & \\
\hline Vehicle & 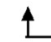 & $\uparrow$ & $\uparrow$ & $\uparrow$ & & I & \\
\hline or PTX & & DAN & GO & & & $\mathrm{PGE}_{2}$ & \\
\hline
\end{tabular}

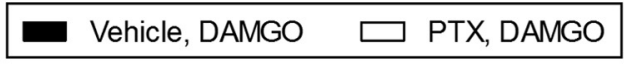

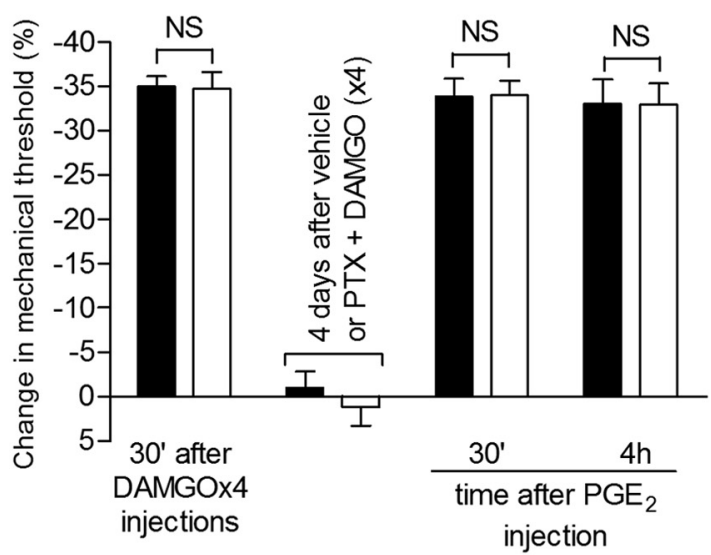

B
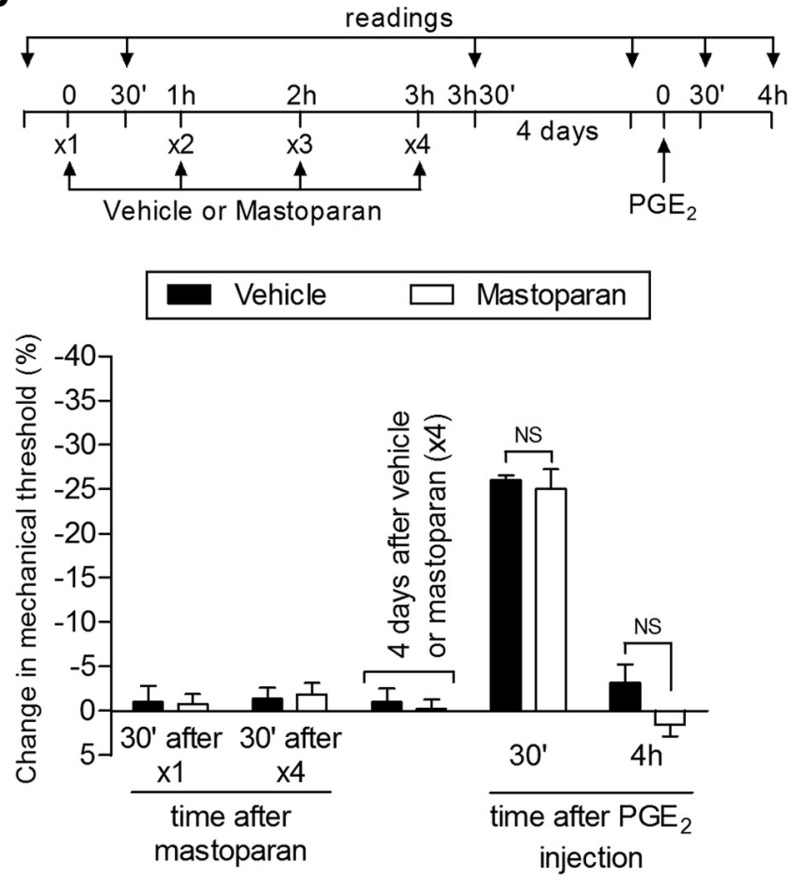

Figure 9. Role of the inhibitory $\mathrm{G}$-protein $\alpha_{\mathrm{i}}$ subunit in type II priming. $\boldsymbol{A}$, Rats received an intradermal injection of vehicle (control, black bars) or PTX ( $1 \mu \mathrm{g}$, white bars) on the dorsum of the hindpaw. Thirty minutes later, DAMGO $(1 \mu \mathrm{g})$ was injected (hourly, $\times 4)$ in the same site. We observed significant mechanical hyperalgesia after the fourth injection of DAMG0, with no significant (NS) difference between groups $\left(t_{(5)}=0.1075, p=0.9186\right.$, control vs PTX groups, unpaired Student's $s$ test), demonstrating that the $\alpha_{\mathrm{i}}$ subunit does not play a role in the hyperalgesia induced by repeated injection of DAMGO. Four days later, when the mechanical thresholds were not different from the prevehicle/PTXinjection levels $\left(t_{(5)}=0.3384 ; p=0.7488\right.$ and $t_{(5)}=0.5547 ; p=0.6030$, respectively, paired Student's $t$ test), rats received intradermal injection of $P G E_{2}(100 \mathrm{ng})$ in the same site and mechanical hyperalgesia was evaluated 30 min and $4 \mathrm{~h}$ later. No significant difference was observed in $\mathrm{PGE}_{2}$-induced mechanical hyperalgesia evaluated 30 min and $4 \mathrm{~h}$ after injection $\left(F_{(1,20)}=0.17 ; p=0.6859\right.$, when comparing both groups; NS, $p>0.05$, two-way repeated-measures ANOVA followed by Bonferroni post hoc hyperalgesia induced by the fourth dose of DAMGO and the prolongation of $\mathrm{PGE}_{2}$ hyperalgesia after repeated administration of DAMGO (Fig. $7 A)$. In rats pretreated with DAMGO $(\times 4)$, $\mathrm{PGE}_{2}$ hyperalgesia was already attenuated $30 \mathrm{~min}$ after its injection in the paws of the PLC- $\beta 3$ AS-ODN-treated rats, suggesting a change in the signaling pathway downstream of the prostaglandin receptor in the hyperalgesia induced by $\mathrm{PGE}_{2}$ in the setting of type II priming; $\mathrm{PGE}_{2}$-induced hyperalgesia in the naive rat is not PLC- $\beta 3$ dependent (Joseph et al., 2007). In addition, when $\mathrm{PGE}_{2}$ was injected $12 \mathrm{~d}$ later, it produced hyperalgesia that was present $4 \mathrm{~h}$ after injection, indicating that the knock-down of PLC- $\beta 3$ inhibited only the expression of type II priming, and did not prevent its induction (Fig. 7A).

The role of Src in the prolongation of $\mathrm{PGE}_{2}$-induced hyperalgesia induced by previous repeated injection of DAMGO (reversal protocol) was also evaluated. Pretreatment with the Src inhibitor SU6656 did not prevent the induction of hyperalgesia by 4 injections of DAMGO, although, similar to the PLC- $\beta 3$ AS-ODN, it did prevent the prolongation of the hyperalgesia induced by injection of $\mathrm{PGE}_{2} 2 \mathrm{~d}$ later (Fig. $7 \mathrm{~B}$ ). Moreover, injection of the Src inhibitor SU6656 significantly inhibited the prolongation of $\mathrm{PGE}_{2}$-induced hyperalgesia in DAMGO-induced priming $4 \mathrm{~d}$ later (Fig. $7 C$ ), indicating a role of Src in the expression of type II priming. Inhibition of other intracellular second messengers shown to play a role in nociceptor sensitization, PLC $\gamma$, caspase, PI3K, nitric oxide synthase, and intracellular calcium (Malik-Hall et al., 2005; Bogen et al., 2008; Joseph et al., 2008; Cunha et al., 2010; Alves et al., 2013; Alkhani et al., 2014; Khomula et al., 2014), did not affect the prolongation of $\mathrm{PGE}_{2}$ hyperalgesia observed after repeated injection of DAMGO (Fig. 8 ), ruling out their involvement in type II priming. The differential effect of the two inhibitors at $30 \mathrm{~min}$ for $\mathrm{PGE}_{2}$ hyperalgesia (Fig. $7 A$ for PLC- $\beta 3$ AS-ODN and Fig. $7 B$ for SU6656) suggests that, at least in part, distinct mechanisms may be involved in the hyperalgesia induced by DAMGO and in the prolongation of $\mathrm{PGE}_{2}$ hyperalgesia in DAMGO-induced type II priming.

\section{Type II priming involves changes in G-protein subunit signaling}

The pronociceptive prostaglandin receptor at which $\mathrm{PGE}_{2}$ acts to produce mechanical hyperalgesia has been described as activating intracellular signaling pathways through a stimulatory G-protein $\left(\mathrm{G}_{\mathrm{s}}\right)$ (Khasar et al., 2008). However, in type I priming, we observed a contribution of an additional, indirect pronociceptive signaling pathway involving activation of a pertussis toxin (PTX)-sensitive inhibitory G-protein $\left(G_{i}\right)$ coupled to the A1 adenosine receptor (Ferrari et al., 2013a). Because MOR is also a $\mathrm{G}_{\mathrm{i}}$-coupled receptor, to evaluate a possible role of inhibitory

$\leftarrow$

test), indicating that the $\alpha_{\mathrm{i}}$ subunit does not play a role in the prolongation of $\mathrm{PGE}_{2}$ hyperalgesia in type II priming; $\boldsymbol{B}$, Rats received repeated (hourly, $\times 4$ ) intradermal injections of the G-protein $\alpha_{\mathrm{i}}$ subunit peptide activator mastoparan $(1 \mu \mathrm{g})$ on the dorsum of the hindpaw. The mechanical nociceptive threshold was evaluated before and $30 \mathrm{~min}$ after the first and fourth administrations. Unpaired Student's $t$ test showed that the injection of mastoparan did not induce significant change in the mechanical nociceptive threshold $(p=1.0000)$ even after 4 hourly administrations compared with the control group. Four days later, PGE $_{2}(100 \mathrm{ng})$ was injected at the same site and mechanical thresholds were evaluated after $30 \mathrm{~min}$ and $4 \mathrm{~h}$. In both groups, we observed significant mechanical hyperalgesia induced by $\mathrm{PGE}_{2} 30$ min after injection (NS, $p>0.05$ ) that was no longer present at the fourth hour $\left(\mathrm{NS}_{2} F_{(1,20)}=2.14 ; p=\right.$ 0.1747 , when comparing both groups at the fourth hour after $\mathrm{PGE}_{2}$ injection; $\mathrm{NS}, p>0.05$ ), indicating that an activator of $\mathrm{G}$-protein $\alpha_{\mathrm{i}}$ subunit does not induce priming. $n=6$ paws per group. 

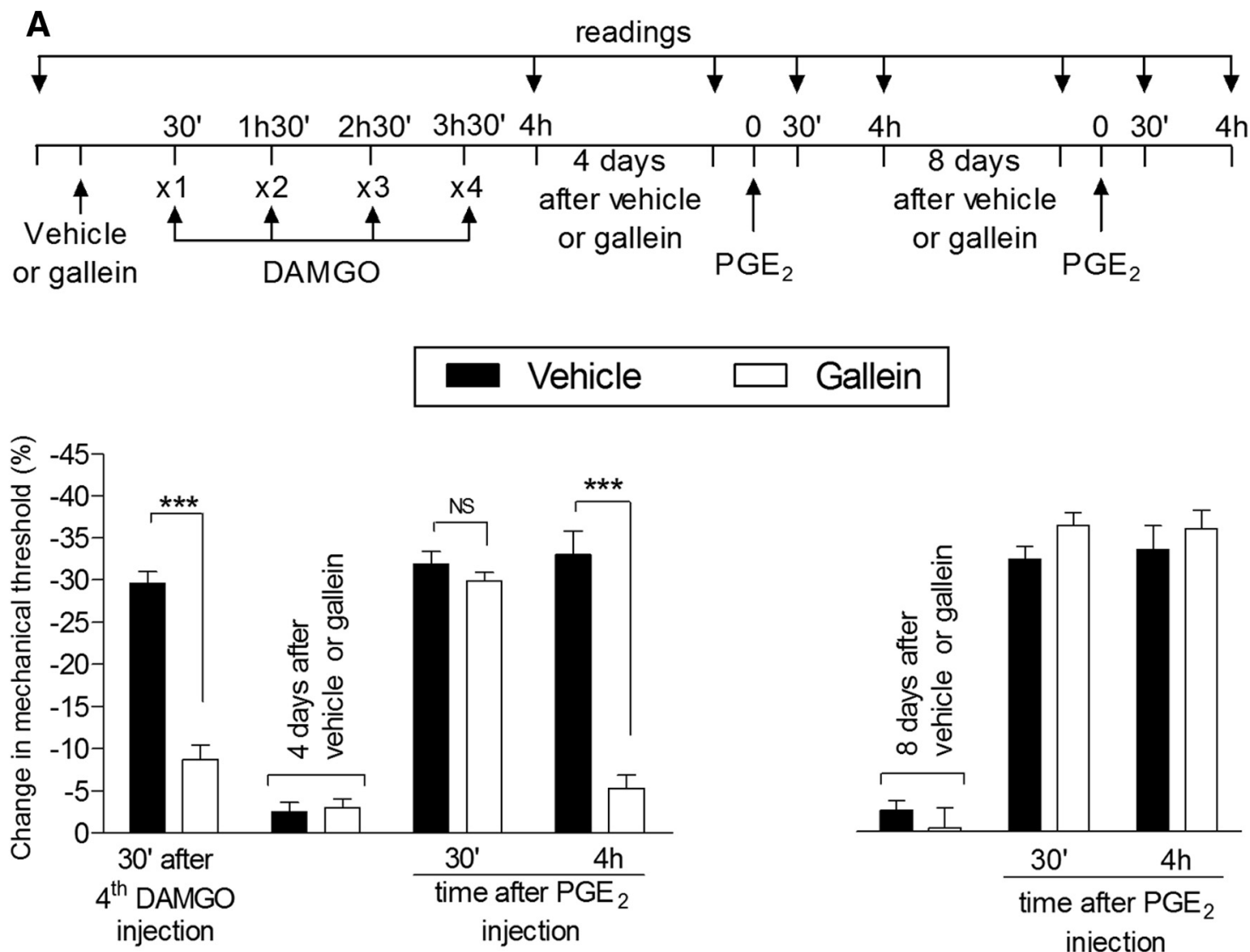

B

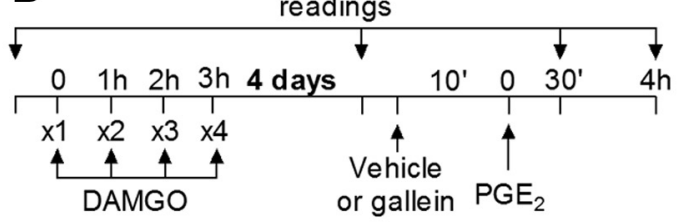

Vehicle $\square$ Gallein

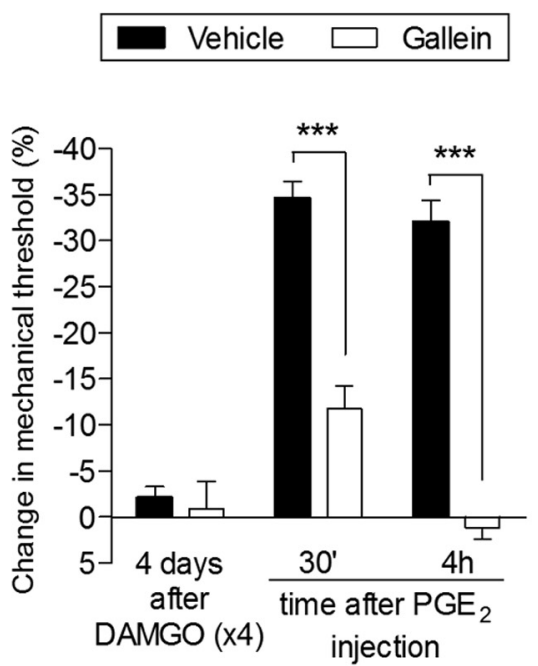

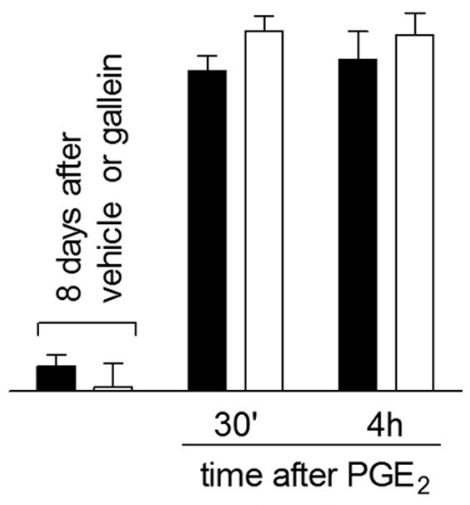

injection

C

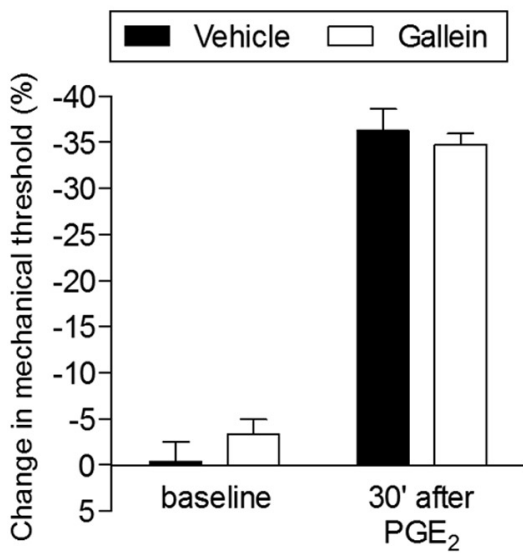

Figure 10. Type II priming is dependent on the G-protein $\beta / \gamma$ subunit. $\boldsymbol{A}$, Rats were treated with intradermal injection of vehicle (control, black bars) or the G-protein $\beta / \gamma$ inhibitor gallein (1 $\mu \mathrm{g}$, white bars) on the dorsum of the hindpaw. Thirty minutes later, repeated injections (hourly, $\times 4)$ of DAMGO $(1 \mu \mathrm{g})$ were performed at the same site and the mechanical nociceptive threshold was evaluated 30 min after the fourth administration. We observed significant mechanical hyperalgesia after the fourth injection of DAMGO in the group pretreated with vehicle, but not in the group pretreated with gallein $\left({ }^{* * *} p=0.0001\right.$ when both groups are compared, paired Student's $t$ test). Four days later, a time point when the mechanical thresholds were not different from preinjection levels $\left(t_{(5)}=2.150 ; p=0.0842\right.$, for the control group and $t_{(5)}=1.530 ; p=0.1852$, for the gallein group; paired Student's $t$ test), rats received intradermal injection of PGE $\left(100 \mathrm{ng}_{2}\right)$ at the same site and mechanical hyperalgesia was evaluated $30 \mathrm{~min}$ and $4 \mathrm{~h}$ later. Although in both groups $\mathrm{PGE}_{2}$-induced mechanical hyperalgesia was present 30 min after injection (NS, $p>0.05$ ), in the gallein-treated group, it was markedly attenuated at the fourth hour $\left(F_{(1,20)}=36.20,{ }^{* * *} p<0.0001\right.$, when control and gallein groups are compared at the (Figure legend continues.) 
G-proteins in the changes in the nociceptor produced by repeated injection of DAMGO, we first tested whether the $\mathrm{G}_{\mathrm{i}} \alpha$ subunit inhibitor PTX would prevent the induction of DAMGO hyperalgesia and the prolongation of $\mathrm{PGE}_{2}$ hyperalgesia after repeated DAMGO injection. We found that pretreatment with PTX does not affect the hyperalgesia produced by a fourth injection of DAMGO nor the prolongation of the hyperalgesia (i.e., still present at the fourth hour after injection) induced by injection of $\mathrm{PGE}_{2} 4 \mathrm{~d}$ later (Fig. 9A). Moreover, the repeated activation of the $\mathrm{G}_{\mathrm{i}}$ protein $\alpha$ subunit by administration of mastoparan did not induce priming (Fig. 9B), providing further support that $G_{i}$ does not participate in the induction of type II priming.

Therefore, we next tested whether the G-protein $\beta / \gamma$ subunit plays a role in type II priming. Pretreatment (prevention protocol) with the G-protein $\beta / \gamma$ subunit inhibitor gallein reversibly inhibited the expression of type II priming; that is, it attenuated both the hyperalgesia induced by a fourth injection of DAMGO and the prolongation of the hyperalgesia produced by injection of $\mathrm{PGE}_{2} 4 \mathrm{~d}$ later (Fig. $10 A$, left), but this effect was temporary because, $8 \mathrm{~d}$ after gallein, the administration of $\mathrm{PGE}_{2}$ produced prolonged hyperalgesia (Fig. 10A, right). A similar effect of gallein was also observed in the inhibition protocol, in which the hyperalgesia induced by $\mathrm{PGE}_{2}$ in rats that had received repeated injections of DAMGO $4 \mathrm{~d}$ prior was markedly attenuated (Fig. 10B). This inhibitory effect of gallein on $\mathrm{PGE}_{2}$ hyperalgesia was already observed 30 min after $\mathrm{PGE}_{2}$ injection, compatible with the suggestion of a change in the signaling pathway activated by $\mathrm{PGE}_{2}$ because gallein in the naive rat does not affect the hyperalgesia induced by $\mathrm{PGE}_{2}$ (Fig. 10C). Repeated

\footnotetext{
$\leftarrow$

(Figure legend continued.) fourth hour after $\mathrm{PGE}_{2}$ injection; two-way repeated-measures ANOVA followed by Bonferroni post hoc test). However, when $\mathrm{PGE}_{2}$ was injected again $8 \mathrm{~d}$ later, it produced mechanical hyperalgesia that was still present $4 \mathrm{~h}$ after injection, indicating that the inhibition of the induction of type II priming by gallein was reversible; $\boldsymbol{B}$, Rats that were treated with repeated hourly $(X 4)$ injections of DAMGO on the dorsum of the hindpaw received vehicle (control, black bars) or gallein ( $1 \mu \mathrm{g}$, white bars) $4 \mathrm{~d}$ later at the same site followed 10 min later by $\mathrm{PGE}_{2}(100 \mathrm{ng})$. Average mechanical nociceptive thresholds before and $4 \mathrm{~d}$ after treatment with DAMG0 were $122.7 \pm 0.8 \mathrm{~g}$ and $120.3 \pm 1.4 \mathrm{~g}$, respectively, for the control and the gallein group. Paired Student's $s$ test showed no difference between these values $\left(t_{(5)}=0.6670 ; p=\right.$ 0.5343 for the control group and $t_{(5)}=0.7559 ; p=0.4838$ for the gallein group). Evaluation of the mechanical nociceptive threshold $30 \mathrm{~min}$ and $4 \mathrm{~h}$ after $\mathrm{PGE}_{2}$ showed significant attenuation of the hyperalgesia induced by $\mathrm{PGE}_{2}$ at both time points in the group treated with gallein $\left(F_{(1,12)}=83.65,{ }^{* * *} p<0.0001\right.$ when both groups are compared, two-way repeatedmeasures ANOVA followed by Bonferroni post hoc test), indicating that, in the setting of the neuroplasticity induced by repeated injections of DAMGO, $\mathrm{PGE}_{2}$-induced hyperalgesia depends on the $G$-protein $\beta / \gamma$ subunit; $C$, Rats treated with intradermal injection of vehicle $(5 \mu$ l, black bars) or gallein (1 $\mu$ g, white bars) received $\mathrm{PGE}_{2}(100 \mathrm{ng}) 30$ min later at the same site. We observed significant mechanical hyperalgesia, evaluated $30 \mathrm{~min}$ after the injection of $\mathrm{PGE}_{2}$, in both groups ( $p>0.05$ control-vs gallein-treated groups, two-way repeated-measures ANOVA followed by Bonferroni post hoc test), indicating that the $\beta / \gamma$ subunit is not involved in the hyperalgesic effect of $\mathrm{PGE}_{2}$ in the naive rat. $n=6$ paws per group.
}

injection of the G-protein $\beta \gamma$ peptide, an activator of G-protein $\beta / \gamma$, did not induce mechanical hyperalgesia after a fourth injection, nor did it produce prolongation of $\mathrm{PGE}_{2}$ hyperalgesia (Fig. 11 ), suggesting that activation of the $\beta / \gamma$ subunit alone is insufficient to induce type II priming.

\section{Changes in PKA signaling in type II priming}

It has been reported that chronic administration of MOR agonists lead to supersensitization of cAMP signaling (Sharma et al., 1975b; Brandt et al., 1976; Bie et al., 2005; Al-Hasani and Bruchas, 2011). Therefore, we next addressed which step in the signaling pathway acts to produce this prolongation; its heterotrimeric stimulatory G-protein (Dina et al., 2009) at the level of adenylyl cyclase (Taiwo and Levine, 1991; Parada et al., 2005) or PKA (Aley and Levine, 1999). To explore the role of the components of the adenylyl cyclase-cAMP-PKA second messenger pathway in the expression of type II hyperalgesic priming, we injected 8-bromo cAMP, a potent membrane-permeable cAMP analog that activates PKA, to evaluate whether this produces prolonged hyperalgesia in the setting of type II priming. If so, the administration of activators of more proximal steps in the pathway would add no additional information with respect to mechanism. We found that injection of 8-bromo cAMP produced prolonged mechanical hyperalgesia in MOR agonist-pretreated rats (Fig. 12A).

To determine whether the prolonged hyperalgesia is due to continued activation of PKA as opposed to activity of a target mechanism downstream of PKA, we administered, in rats previously treated with repeated injections of DAMGO the PKA inhibitor H-89 $60 \mathrm{~min}$ after injection of 8-bromo cAMP, a time point 
A

\begin{tabular}{|c|c|c|c|c|}
\hline \multicolumn{5}{|c|}{ readings } \\
\hline$\downarrow$ & & & $\downarrow$ & $\downarrow$ \\
\hline 0 & $1 \mathrm{~h}$ & $2 \mathrm{~h}$ & $3 \mathrm{~h} 3 \mathrm{~h} 30^{\prime}$ & $7 \mathrm{~h}$ \\
\hline 51 & 11 & $\begin{array}{r}11 \\
\times 3\end{array}$ & 1 & \\
\hline $\begin{array}{c}x 1 \\
4\end{array}$ & $\mathrm{x} 2$ & $\begin{array}{r}\times 3 \\
4\end{array}$ & & \\
\hline & $\begin{array}{l}\text { hicle } \\
\text { AMG }\end{array}$ & & $\begin{array}{l}\text { 8-bromo } \\
\text { cAMP }\end{array}$ & \\
\hline
\end{tabular}

\section{Vehicle $\times 3,8$-bromo cAMP $\square$ DAMGO $\times 3,8$-bromo cAMP}

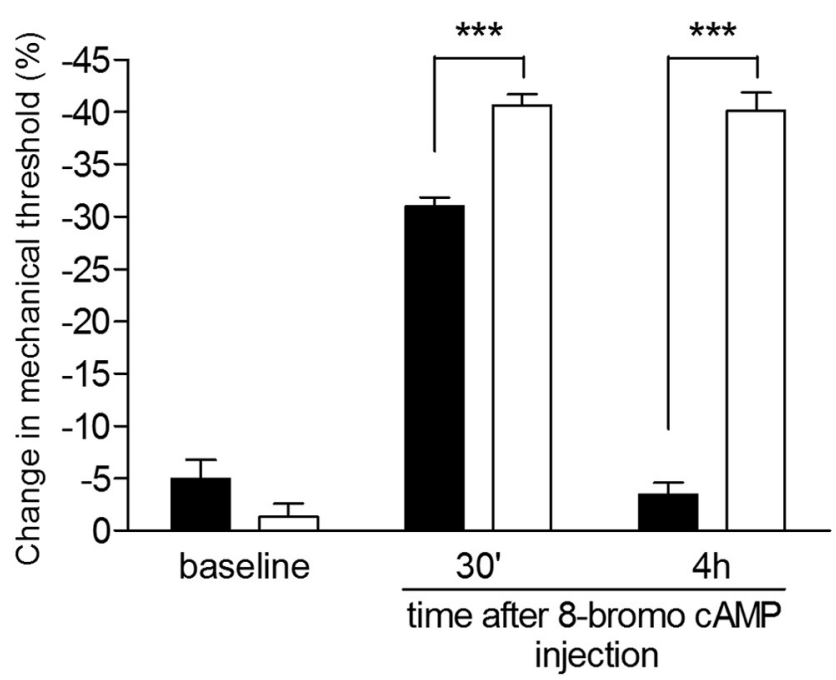

B
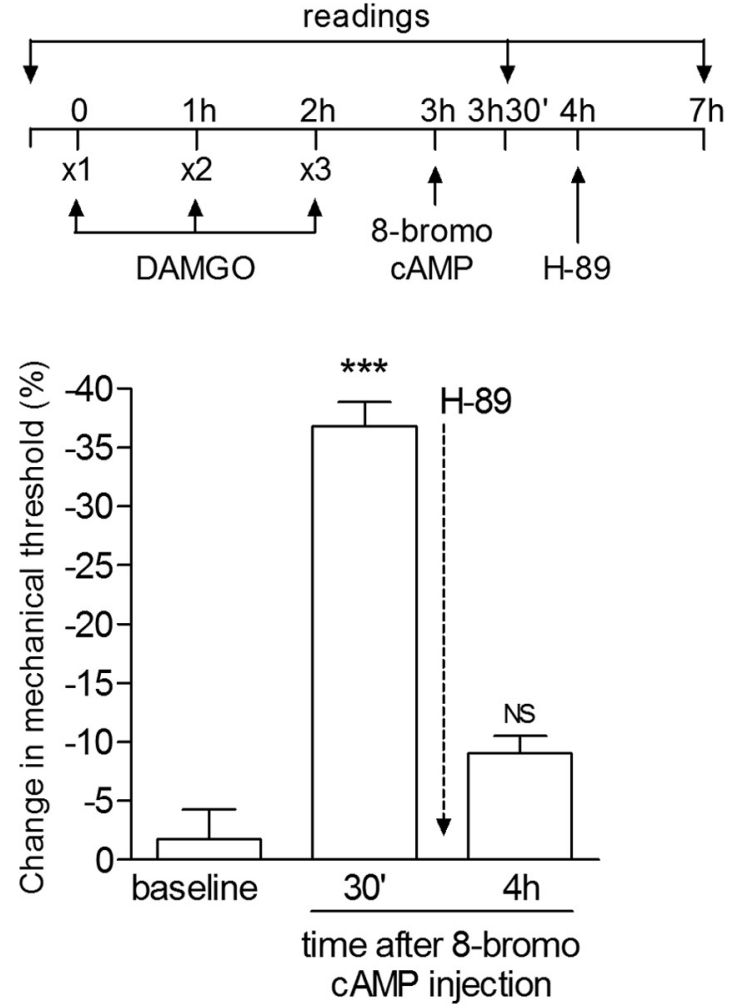

Figure 12. Changes in PKA signaling contribute to the prolongation of $\mathrm{PGE}_{2}$-induced hyperalgesia in type II priming. $\boldsymbol{A}$, Rats received 3 hourly intradermal injections of vehicle or DAMGO $(1 \mu \mathrm{g})$ on the dorsum of the hindpaw. 8-bromo cAMP $(1 \mu \mathrm{g})$ was injected at the same site $1 \mathrm{~h}$ later and mechanical hyperalgesia was evaluated after $30 \mathrm{~min}$ and $4 \mathrm{~h}$. 8-bromo cAMP produced when its hyperalgesic effect would no longer be present in a control animal (Taiwo et al., 1989; Taiwo and Levine, 1991). We observed that, at this time point, $\mathrm{H}-89$ was able to reverse the prolonged hyperalgesia induced by 8-bromo cAMP (Fig. 12B), supporting the suggestion that there is a change in PKA signaling associated with type II priming that is responsible for the prolongation of $\mathrm{PGE}_{2}$-induced mechanical hyperalgesia.

Because we have observed that PKA has a role in DAMGOinduced neuroplasticity and considering reports of long-lasting sensitization of PKA signaling as a result of proteasome-mediated degradation of the regulatory subunit of PKA (Greenberg et al., 1987; Chain et al., 1999; Moss et al., 2002), we investigated whether treatment with a proteasome inhibitor, MG-132, would affect the induction of type II priming by repeated injection of DAMGO. MG-132 did not, however, have any effect on DAMGO-induced priming (Fig. 13).

\section{Discussion}

Repeated administration of DAMGO produces a long-lasting change in nociceptor function such that subsequent doses produce mechanical hyperalgesia (Aley et al., 1995). Further, the administration of $\mathrm{PGE}_{2}$ as soon as $1 \mathrm{~h}$ after 3 doses of DAMGO produced markedly prolonged hyperalgesia, similar to $\mathrm{PGE}_{2}$ hyperalgesia in the setting of type I, hyperalgesic priming (Joseph et al., 2010). This effect of a subsequent dose of DAMGO or a dose of $\mathrm{PGE}_{2}$ was still present without attenuation for $>1$ month. None of the several second messenger inhibitors tested, including those for second messengers implicated in type I priming, prevented the development of the neuroplasticity triggered by the repeated injection of DAMGO.

The involvement of the $\alpha_{\mathrm{i}} \mathrm{G}$-protein subunit was considered with respect to the expression of type II priming. Although PTX, an inhibitor of $\alpha_{i}$, inhibited the prolongation of $\mathrm{PGE}_{2}$ hyperalgesia in the setting of type I hyperalgesic priming (Ferrari et al., 2013a), it failed to inhibit DAMGO hyperalgesia or the prolongation of $\mathrm{PGE}_{2}$ hyperalgesia in type II priming. These findings support the suggestion that, for changes at a very proximal step in signal transduction, the mechanism of DAMGO-induced type II priming can already be distinguished from that for type I hyperalgesic priming. In addition, unlike type I priming, the prolongation of $\mathrm{PGE}_{2}$-induced hyperalgesia in rats pretreated with DAMGO is not attenuated by the PKC $\varepsilon$ inhibitor $\mathrm{PKC} \varepsilon_{\mathrm{V} 1-2}$. To determine which second messengers mediate the induction of type II priming, we evaluated the role of the adenylyl cyclasecAMP-PKA second messenger pathway, which has been implicated in nociceptor sensitization (Aley and Levine, 1999), in DAMGO-induced hyperalgesia and prolongation of $\mathrm{PGE}_{2}$ hyperalgesia. We found that pretreatment with the PKA inhibitor H-89 attenuated DAMGO hyperalgesia and the prolongation of $\mathrm{PGE}_{2}$

$\leftarrow$

mechanical hyperalgesia in both groups at $30 \mathrm{~min}$. However, in the group previously treated with DAMGO, it was significantly enhanced and prolonged and still present after $4 \mathrm{~h}$, as opposed to the vehicle-treated group $\left(F_{(1,20)}=96.82 ;{ }^{* *} p<0.0001\right.$, when comparing both groups; two-way repeated-measures ANOVA followed by Bonferroni post hoc test), suggesting an increased activation of PKA signaling by repeated MOR activation; $\boldsymbol{B}$, Rats received 3 hourly intradermal injections of DAMGO $(1 \mu \mathrm{g})$ on the dorsum of the hindpaw and a fourth injection of 8-bromo CAMP $(1 \mu \mathrm{g})$ at the same site. Significant mechanical hyperalgesia was observed 30 min later. Injection of H-89 $(1 \mu \mathrm{g}) 1 \mathrm{~h}$ after 8-bromo cAMP inhibited the ongoing hyperalgesia evaluated $3 \mathrm{~h}$ later that was produced by the previous treatment with repeated injections of DAMGO (NS, $p>0.05$ vs baseline; one-way repeated-measures ANOVA followed by Bonferroni post hoc test), indicating a role of PKA in the increased activation of the CAMP signaling pathway produced by repeated MOR agonist administration. $n=6$ paws per group. 
hyperalgesia. However, when $\mathrm{PGE}_{2}$ was injected again $30 \mathrm{~d}$ later, it induced prolonged hyperalgesia. These results support a role of the adenylyl cyclasecAMP-PKA pathway in the expression of type II priming. In addition, because we have shown previously that the Src inhibitor SU6656 and antisense to PLC- $\beta 3$ inhibited PKA-dependent prolongation of $\mathrm{PGE}_{2}$ hyperalgesia in rats primed by the transient reduction of GRK2 (Ferrari et al., 2012), we evaluated their effect on the hyperalgesia induced by injection of DAMGO or $\mathrm{PGE}_{2}$ in the setting of DAMGO-induced priming. Whereas in rats submitted to repeated injection of DAMGO, SU6656 and antisense to PLC- $\beta 3$ both also inhibited the prolongation of $\mathrm{PGE}_{2}$-induced hyperalgesia, but only the PLC- $\beta 3$ antisense inhibited DAMGO hyperalgesia. The interaction of these second messengers in type II priming remains to be determined.

Supersensitization in the adenylyl cyclase-cAMP-PKA signaling pathway has been demonstrated in the setting of opioid dependence (Sharma et al., 1975a; Brandt et al., 1976; Al-Hasani and Bruchas, 2011). To determine whether there is supersensitization in this signaling pathway, we directly activated PKA, in DAMGO-pretreated rats, by intradermal administration of 8-bromo cAMP. In DAMGO-primed animals, 8-bromo cAMP induced prolonged mechanical hyperalgesia, supporting the suggestion that PKA signaling, or a downstream target of PKA, contributes to the prolongation of hyperalgesia. To determine whether a change in function at the level of PKA could alone account for the prolongation of hyperalgesia, we administered the PKA inhibitor during the prolongation phase of 8-bromo cAMP-induced hyperalgesia. That 8-bromo cAMP induces prolonged hyperalgesia and H-89 markedly attenuates the prolongation phase of 8 -bromo cAMPinduced hyperalgesia supports the suggestion that a change in signaling by PKA contributes to the prolongation of 8-bromo cAMP in type II priming. Although it is known that the repeated activation of MOR can lead to supersensitization of adenylyl cyclase (Sharma et al., 1975a; Brandt et al., 1976; Al-Hasani and Bruchas, 2011), the findings of the present study are, to the best of our knowledge, the first evidence that it can also induce supersensitization at the level of PKA.

We next addressed possible mechanisms for the supersensitization of PKA. It has been suggested that proteasome-mediated degradation of the regulatory subunit of PKA can produce a long-lasting sensitization of PKA signaling such that even a low concentration of cAMP can induce PKA activation (Yang et al., 2008; Myeku et al., 2012). However, intradermal injection of the proteasome inhibitor MG132 did not prevent DAMGO-induced priming. Alternative mechanisms include autophosphorylation of PKA (Yonemoto et al., 1993; Cauthron et al., 1998; Cheng et al., 1998) or involvement of other elements of its signaling pathway, for example, GRK2 (Penela et al., 1998; Ferrari et al., 2012). We showed recently that a transient decrease in GRK2 also produces a form of hyperalgesic priming that
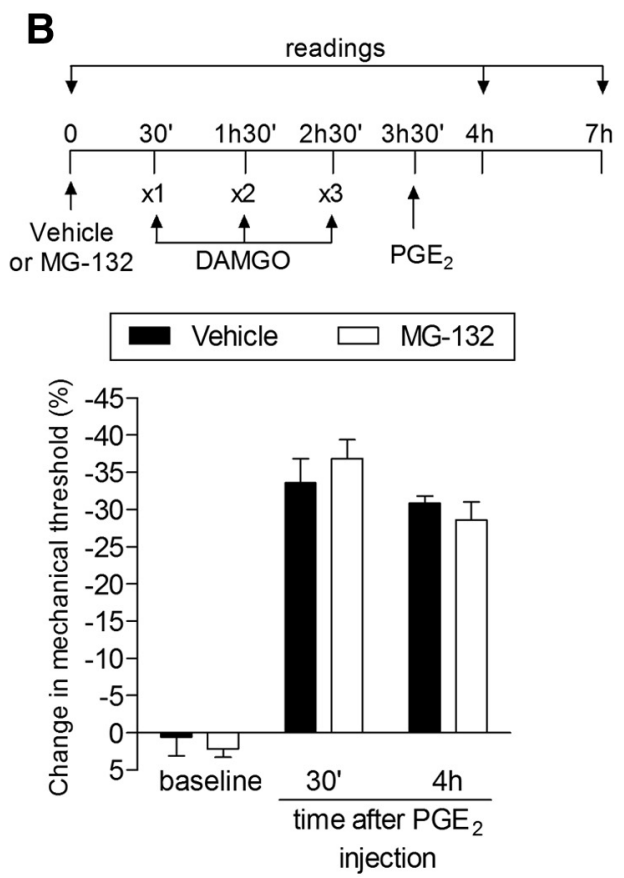

injection

Figure 13. Proteasome inhibitor does not affect type II priming. $A$, Rats were treated with intradermal injection of the proteasome inhibitor MG-132 (1 $\mu \mathrm{g})$ on the dorsum of the hindpaw. Thirty minutes later, repeated (hourly, $\times 4)$ injections of DAMGO ( the proteasome system does not play a role in the prolongation of the hyperalgesia induced by $P G E_{2}$ observed in type II priming

is not inhibited by a selective PKC $\varepsilon$ inhibitor, which inhibits type I priming (Ferrari et al., 2012), and is not reversed by cordycepin, which permanently reverses type I priming (Ferrari et al., 2013b). Like DAMGO-induced priming, however, this form of priming is inhibited by a selective PKA inhibitor. GRK2 is a $\beta / \gamma$ subunit effector (Willets et al., 2003; Smrcka, 2008) and $\beta / \gamma$ signaling can be blocked by GRK2 (Smrcka, 2008; Casey et al., 2010). Exactly how signaling between inhibiting $\beta / \gamma$ and GRK2 could contribute remains to be established.

In our previous study of the priming induced by the transient attenuation of GRK2 using a large panel of second messenger inhibitors, the only other inhibitors (in addition to that for PKA) that attenuated the prolongation of $\mathrm{PGE}_{2}$ hyperalgesia were an Src inhibitor, SU6656, and PLC- $\beta 3$ antisense (Ferrari et al., 2012). SU6656 also attenuated the prolongation of $\mathrm{PGE}_{2}$ hyperalgesia in type II priming, without affecting DAMGO hyperalgesia. Although it is known that $\beta / \gamma$ subunits signal via Src (Luttrell et al., 1997), the pathway connecting PKA and Src in the expression of type II priming remains to be established. However, in our prior study of priming induced by a transient decrease in GRK2, we did observe that the coadministration of a PKA and Src inhibitors produced no greater reversal of hyperalgesia than either alone (Ferrari et al., 2012), compatible with a shared signaling pathway in which Src is downstream of PKA (Burmeister et al., 2012; Ickowicz et al., 2012).

Although type II and I priming are both dependent on Giprotein coupled receptor signaling, each uses this G-protein complex differently. In type I priming, receptors that activate 
$\mathrm{PKC} \varepsilon$ produce a change in adenosine $\mathrm{A} 1$ receptor signaling, such that the A1 receptor agonist now induces hyperalgesia (Ferrari et al., 2013a). Although this receptor still activates $\alpha_{\mathrm{i}}$ to mediate CPA-induced hyperalgesia, it now signals to activate $\mathrm{PKC} \varepsilon$ rather than inhibit AC-PKA. In contrast, in type II priming, repeated MOR activation produces a state in which the activation of these receptors leads to prolongation of $\mathrm{PGE}_{2}$-induced mechanical hyperalgesia that is $\beta / \gamma$ and PKA dependent. Although it is currently unknown to what downstream molecule the MOR signals to induce type II hyperalgesic priming, it is known that the $\beta / \gamma$ subunit does signal bidirectionally to GRK2 (Smrcka, 2008) and that transient attenuation of GRK2 produces type II-like priming (Ferrari et al., 2012).

Although type I priming is mediated by $\mathrm{IB} 4{ }^{+}$nociceptors (Joseph and Levine, 2010a), type II priming is mediated by IB4 ${ }^{-}$nociceptors, as indicated by our finding that the prolongation of $\mathrm{PGE}_{2}$-induced hyperalgesia produced by previous repeated injection of DAMGO was not attenuated by IB4saporin. In fact, DAMGO-induced hyperalgesia was significantly increased in IB4-saporin treated rats, which may suggest an interaction between the different subtypes of nociceptors in the expression of type II priming. In addition, different from type I priming induced by PKC $\varepsilon$ (Ferrari et al., 2015), type II priming can be induced in both males and females. This is consistent with animal studies (Holtman and Wala, 2007; Elhabazi et al., 2014) and clinical reports (Konopka and van Wijhe, 2010; Schneider and Kirsh, 2010; Akarsu et al., 2012) showing that chronic opioid exposure can produce hyperalgesia as well as tolerance, two conditions that can overlap and be difficult to separate in clinical circumstances (Bekhit, 2010; Chu et al., 2012; Angst, 2015), in both sexes (Konopka and van Wijhe, 2010; Schneider and Kirsh, 2010; Edwards et al., 2011).

Finally, although it has been suggested that opioid-induced hyperalgesia may be due to onset of withdrawal, between opioid doses (Mercadante and Arcuri, 2005; Chu et al., 2008; Chen et al., 2009; Hay et al., 2009; Lee et al., 2011), our finding that the administration of a fourth dose of DAMGO induces a rapid onset mechanical hyperalgesia that was significant by $5 \mathrm{~min}$ after injection supports a switch in MOR signaling from an ability to reverse cAMP-dependent hyperalgesia to induction of hyperalgesia. Although the role of type II priming in chronic pain syndromes remains to be established, inflammation can induce a reversible decrease in GRK2 (Kleibeuker et al., 2007; Eijkelkamp et al., 2010), suggesting a possible role in the transition to chronic pain associated with inflammatory diseases (Ferrari et al., 2012). How one might reverse (treat) a chronic pain condition mediated by type II hyperalgesic priming remains a key question.

\section{References}

Akarsu M, Tuncer S, Reisli R, Otelcioğlu S (2012) The role of magnesium in preventing postoperative hyperalgesia [article in Turkish]. Agri 24:15-22. CrossRef Medline

Aley KO, Levine JD (1997a) Dissociation of tolerance and dependence for opioid peripheral antinociception in rats. J Neurosci 17:3907-3912. Medline

Aley KO, Levine JD (1997b) Multiple receptors involved in peripheral alpha 2, $\mathrm{mu}$, and $\mathrm{Al}$ antinociception, tolerance, and withdrawal. J Neurosci 17:735-744. Medline

Aley KO, Levine JD (1999) Role of protein kinase A in the maintenance of inflammatory pain. J Neurosci 19:2181-2186. Medline

Aley KO, Green PG, Levine JD (1995) Opioid and adenosine peripheral antinociception are subject to tolerance and withdrawal. J Neurosci 15: 8031-8038. Medline

Aley KO, Messing RO, Mochly-Rosen D, Levine JD (2000) Chronic hyper- sensitivity for inflammatory nociceptor sensitization mediated by the epsilon isozyme of protein kinase C. J Neurosci 20:4680-4685. Medline

Aley KO, Martin A, McMahon T, Mok J, Levine JD, Messing RO (2001) Nociceptor sensitization by extracellular signal-regulated kinases. J Neurosci 21:6933-6939. Medline

Al-Hasani R, Bruchas MR (2011) Molecular mechanisms of opioid receptor-dependent signaling and behavior. Anesthesiology 115:13631381. Medline

Alkhani H, Ase AR, Grant R, O’Donnell D, Groschner K, Seguela P (2014) Contribution of TRPC3 to store-operated calcium entry and inflammatory transductions in primary nociceptors. Mol Pain 10:43. CrossRef Medline

Alves DP, da Motta PG, Romero TR, Klein A, Duarte ID (2013) NO/cGMP production is important for the endogenous peripheral control of hyperalgesia during inflammation. Nitric Oxide 28:8-13. CrossRef Medline

Angst MS (2015) Intraoperative use of remifentanil for tiva: postoperative pain, acute tolerance, and opioid-induced hyperalgesia. J Cardiothorac Vasc Anesthe 29:S16-S22. CrossRef Medline

Angst MS, Clark JD (2006) Opioid-induced hyperalgesia: a qualitative systematic review. Anesthesiology 104:570-587. CrossRef Medline

Bekhit MH (2010) Opioid-induced hyperalgesia and tolerance. Am J Ther 17:498-510. CrossRef Medline

Bie B, Peng Y, Zhang Y, Pan ZZ (2005) cAMP-mediated mechanisms for pain sensitization during opioid withdrawal. J Neurosci 25:3824-3832. CrossRef Medline

Bogen O, Joseph EK, Chen X, Levine JD (2008) GDNF hyperalgesia is mediated by PLCgamma, MAPK/ERK, PI3K, CDK5 and Src family kinase signaling and dependent on the IB4-binding protein versican. Eur J Neurosci 28:12-19. CrossRef Medline

Bogen O, Alessandri-Haber N, Chu C, Gear RW, Levine JD (2012) Generation of a pain memory in the primary afferent nociceptor triggered by PKCepsilon activation of CPEB. J Neurosci 32:2018-2026. CrossRef Medline

Borle AB, Snowdowne KW (1982) Measurement of intracellular free calcium in monkey kidney cells with aequorin. Science 217:252-254. CrossRef Medline

Brandt M, Gullis RJ, Fischer K, Buchen C, Hamprecht B, Moröder L, Wunsch E (1976) Enkephalin regulates the levels of cyclic nucleotides in neuroblastoma x glioma hybrid cells. Nature 262:311-313. CrossRef Medline

Burch RM, Axelrod J (1987) Dissociation of bradykinin-induced prostaglandin formation from phosphatidylinositol turnover in Swiss 3T3 fibroblasts: evidence for $\mathrm{G}$ protein regulation of phospholipase A2. Proc Natl Acad Sci U S A 84:6374-6378. CrossRef Medline

Burmeister BT, Taglieri DM, Wang L, Carnegie GK (2012) Src homology 2 domain-containing phosphatase 2 (Shp2) is a component of the A-kinase-anchoring protein (AKAP)-Lbc complex and is inhibited by protein kinase A (PKA) under pathological hypertrophic conditions in the heart. J Biol Chem 287:40535-40546. CrossRef Medline

Casey LM, Pistner AR, Belmonte SL, Migdalovich D, Stolpnik O, Nwakanma FE, Vorobiof G, Dunaevsky O, Matavel A, Lopes CM, Smrcka AV, Blaxall BC (2010) Small molecule disruption of G beta gamma signaling inhibits the progression of heart failure. Circ Res 107:532-539. CrossRef Medline

Cauthron RD, Carter KB, Liauw S, Steinberg RA (1998) Physiological phosphorylation of protein kinase A at Thr-197 is by a protein kinase A kinase. Mol Cell Biol 18:1416-1423. Medline

Chain DG, Casadio A, Schacher S, Hegde AN, Valbrun M, Yamamoto N, Goldberg AL, Bartsch D, Kandel ER, Schwartz JH (1999) Mechanisms for generating the autonomous cAMP-dependent protein kinase required for long-term facilitation in Aplysia. Neuron 22:147-156. CrossRef Medline

Chen L, Malarick C, Seefeld L, Wang S, Houghton M, Mao J (2009) Altered quantitative sensory testing outcome in subjects with opioid therapy. Pain 143:65-70. CrossRef Medline

Chen Y, Yang C, Wang ZJ (2010) Ca2+/calmodulin-dependent protein kinase II alpha is required for the initiation and maintenance of opioidinduced hyperalgesia. J Neurosci 30:38-46. CrossRef Medline

Cheng X, Ma Y, Moore M, Hemmings BA, Taylor SS (1998) Phosphorylation and activation of cAMP-dependent protein kinase by phosphoinositide-dependent protein kinase. Proc Natl Acad Sci U S A 95:9849-9854. CrossRef Medline

Chu LF, Angst MS, Clark D (2008) Opioid-induced hyperalgesia in humans: molecular mechanisms and clinical considerations. Clin J Pain 24:479-496. CrossRef Medline

Chu LF, D’Arcy N, Brady C, Zamora AK, Young CA, Kim JE, Clemenson AM, 
Angst MS, Clark JD (2012) Analgesic tolerance without demonstrable opioid-induced hyperalgesia: a double-blinded, randomized, placebocontrolled trial of sustained-release morphine for treatment of chronic nonradicular low-back pain. Pain 153:1583-1592. CrossRef Medline

Cunha TM, Talbot J, Pinto LG, Vieira SM, Souza GR, Guerrero AT, Sonego F, Verri WA Jr, Zamboni DS, Ferreira SH, Cunha FQ (2010) Caspase-1 is involved in the genesis of inflammatory hypernociception by contributing to peripheral IL-1beta maturation. Mol Pain 6:63. CrossRef Medline

Dina OA, Khasar SG, Gear RW, Levine JD (2009) Activation of Gi induces mechanical hyperalgesia poststress or inflammation. Neuroscience 160: 501-507. CrossRef Medline

Edwards RR, Wasan AD, Michna E, Greenbaum S, Ross E, Jamison RN (2011) Elevated pain sensitivity in chronic pain patients at risk for opioid misuse. J Pain 12:953-963. Medline

Eijkelkamp N, Heijnen CJ, Willemen HL, Deumens R, Joosten EA, Kleibeuker W, den Hartog IJ, van Velthoven CT, Nijboer C, Nassar MA, Dorn GW 2nd, Wood JN, Kavelaars A (2010) GRK2: a novel cell-specific regulator of severity and duration of inflammatory pain. J Neurosci 30:21382149. CrossRef Medline

Elhabazi K, Ayachi S, Ilien B, Simonin F (2014) Assessment of morphineinduced hyperalgesia and analgesic tolerance in mice using thermal and mechanical nociceptive modalities. J Vis Exp 89:e51264. Medline

Ferrari LF, Levine JD (2015) Plasma membrane mechanisms in a preclinical rat model of chronic pain. J Pain 16:60-66. CrossRef Medline

Ferrari LF, Bogen O, Levine JD (2010) Nociceptor subpopulations involved in hyperalgesic priming. Neuroscience 165:896-901. CrossRef Medline

Ferrari LF, Bogen O, Alessandri-Haber N, Levine E, Gear RW, Levine JD (2012) Transient decrease in nociceptor GRK2 expression produces long-term enhancement in inflammatory pain. Neuroscience 222:392403. CrossRef Medline

Ferrari LF, Levine E, Levine JD (2013a) Role of a novel nociceptor autocrine mechanism in chronic pain. Eur J Neurosci 37:1705-1713. CrossRef Medline

Ferrari LF, Bogen O, Chu C, Levine JD (2013b) Peripheral administration of translation inhibitors reverses increased hyperalgesia in a model of chronic pain in the rat. J Pain 14:731-738. CrossRef Medline

Ferrari LF, Bogen O, Levine JD (2014) Second messengers mediating the expression of neuroplasticity in a model of chronic pain in the rat. J Pain 15:312-320. CrossRef Medline

Ferrari LF, Bogen O, Reichling DB, Levine JD (2015) Accounting for the delay in the transition from acute to chronic pain: axonal and nuclear mechanisms. J Neurosci 35:495-507. CrossRef Medline

Greenberg SM, Castellucci VF, Bayley H, Schwartz JH (1987) A molecular mechanism for long-term sensitization in Aplysia. Nature 329:62-65. CrossRef Medline

Hay JL, White JM, Bochner F, Somogyi AA, Semple TJ, Rounsefell B (2009) Hyperalgesia in opioid-managed chronic pain and opioid-dependent patients. J Pain 10:316-322. CrossRef Medline

Holtman JR Jr, Wala EP (2007) Characterization of the antinociceptive and pronociceptive effects of methadone in rats. Anesthesiology 106:563-571. CrossRef Medline

Ickowicz D, Finkelstein M, Breitbart H (2012) Mechanism of sperm capacitation and the acrosome reaction: role of protein kinases. Asian J Androl 14:816-821. CrossRef Medline

Johnson JA, Gray MO, Chen CH, Mochly-Rosen D (1996) A protein kinase $\mathrm{C}$ translocation inhibitor as an isozyme-selective antagonist of cardiac function. J Biol Chem 271:24962-24966. CrossRef Medline

Joseph EK, Levine JD (2010a) Hyperalgesic priming is restricted to isolectin B4-positive nociceptors. Neuroscience 169:431-435. CrossRef Medline

Joseph EK, Levine JD (2010b) Multiple PKCepsilon-dependent mechanisms mediating mechanical hyperalgesia. Pain 150:17-21. CrossRef Medline

Joseph EK, Parada CA, Levine JD (2003) Hyperalgesic priming in the rat demonstrates marked sexual dimorphism. Pain 105:143-150. CrossRef Medline

Joseph EK, Bogen O, Alessandri-Haber N, Levine JD (2007) PLC-beta 3 signals upstream of PKC epsilon in acute and chronic inflammatory hyperalgesia. Pain 132:67-73. CrossRef Medline

Joseph EK, Chen X, Bogen O, Levine JD (2008) Oxaliplatin acts on IB4positive nociceptors to induce an oxidative stress-dependent acute painful peripheral neuropathy. J Pain 9:463-472. CrossRef Medline

Joseph EK, Reichling DB, Levine JD (2010) Shared mechanisms for opioid tolerance and a transition to chronic pain. J Neurosci 30:4660-4666. CrossRef Medline

Khasar SG, Lin YH, Martin A, Dadgar J, McMahon T, Wang D, Hundle B, Aley KO, Isenberg W, McCarter G, Green PG, Hodge CW, Levine JD, Messing RO (1999) A novel nociceptor signaling pathway revealed in protein kinase C epsilon mutant mice. Neuron 24:253-260. CrossRef Medline

Khasar SG, Burkham J, Dina OA, Brown AS, Bogen O, Alessandri-Haber N, Green PG, Reichling DB, Levine JD (2008) Stress induces a switch of intracellular signaling in sensory neurons in a model of generalized pain. J Neurosci 28:5721-5730. CrossRef Medline

Khomula EV, Borisyuk AL, Viatchenko-Karpinski VY, Briede A, Belan PV, Voitenko NV (2014) Nociceptive neurons differentially express fast and slow T-type $\mathrm{Ca}(2)(+)$ currents in different types of diabetic neuropathy. Neural Plast 2014:938235. Medline

Kleibeuker W, Ledeboer A, Eijkelkamp N, Watkins LR, Maier SF, Zijlstra J, Heijnen CJ, Kavelaars A (2007) A role for G protein-coupled receptor kinase 2 in mechanical allodynia. Eur J Neurosci 25:1696-1704. CrossRef Medline

Kolesnikov YA, Jain S, Wilson R, Pasternak GW (1996) Peripheral morphine analgesia: synergy with central sites and a target of morphine tolerance. J Pharmacol Exp Ther 279:502-506. Medline

Konopka KH, van Wijhe M (2010) Opioid-induced hyperalgesia: pain hurts? Br J Anaesth 105:555-557. CrossRef Medline

Lee M, Silverman SM, Hansen H, Patel VB, Manchikanti L (2011) A comprehensive review of opioid-induced hyperalgesia. Pain Physician 14: 145-161. Medline

Levine JD, Taiwo YO (1989) Involvement of the mu-opiate receptor in peripheral analgesia. Neuroscience 32:571-575. CrossRef Medline

Luttrell LM, Della Rocca GJ, van Biesen T, Luttrell DK, Lefkowitz RJ (1997) Gbetagamma subunits mediate Src-dependent phosphorylation of the epidermal growth factor receptor: a scaffold for $G$ protein-coupled receptor-mediated Ras activation. J Biol Chem 272:4637-4644. CrossRef Medline

Malik-Hall M, Dina OA, Levine JD (2005) Primary afferent nociceptor mechanisms mediating NGF-induced mechanical hyperalgesia. Eur J Neurosci 21:3387-3394. CrossRef Medline

Mao J (2002) Opioid-induced abnormal pain sensitivity: implications in clinical opioid therapy. Pain 100:213-217. CrossRef Medline

Mercadante S, Arcuri E (2005) Hyperalgesia and opioid switching. Am J Hosp Palliat Care 22:291-294. CrossRef Medline

Mestre C, Pélissier T, Fialip J, Wilcox G, Eschalier A (1994) A method to perform direct transcutaneous intrathecal injection in rats. J Pharmacol Toxicol Methods 32:197-200. CrossRef Medline

Moss A, Blackburn-Munro G, Garry EM, Blakemore JA, Dickinson T, Rosie R, Mitchell R, Fleetwood-Walker SM (2002) A role of the ubiquitinproteasome system in neuropathic pain. J Neurosci 22:1363-1372. Medline

Myeku N, Wang H, Figueiredo-Pereira ME (2012) cAMP stimulates the ubiquitin/proteasome pathway in rat spinal cord neurons. Neurosci Lett 527:126-131. CrossRef Medline

Nishiguchi J, Sasaki K, Seki S, Chancellor MB, Erickson KA, de Groat WC Kumon H, Yoshimura N (2004) Effects of isolectin B4-conjugated saporin, a targeting cytotoxin, on bladder overactivity induced by bladder irritation. Eur J Neurosci 20:474-482. CrossRef Medline

Ossipov MH, Lai J, King T, Vanderah TW, Porreca F (2005) Underlying mechanisms of pronociceptive consequences of prolonged morphine exposure. Biopolymers 80:319-324. CrossRef Medline

Parada CA, Yeh JJ, Reichling DB, Levine JD (2003a) Transient attenuation of protein kinase Cepsilon can terminate a chronic hyperalgesic state in the rat. Neuroscience 120:219-226. CrossRef Medline

Parada CA, Yeh JJ, Joseph EK, Levine JD (2003b) Tumor necrosis factor receptor type-1 in sensory neurons contributes to induction of chronic enhancement of inflammatory hyperalgesia in rat. Eur J Neurosci 17: 1847-1852. CrossRef Medline

Parada CA, Reichling DB, Levine JD (2005) Chronic hyperalgesic priming in the rat involves a novel interaction between cAMP and PKCepsilon second messenger pathways. Pain 113:185-190. CrossRef Medline

Penela P, Ruiz-Gómez A, Castaño JG, Mayor F Jr (1998) Degradation of the G protein-coupled receptor kinase 2 by the proteasome pathway. J Biol Chem 273:35238-35244. CrossRef Medline

Quanhong Z, Ying X, Moxi C, Tao X, Jing W, Xin Z, Li W, Derong C, Xiaoli Z, Wei J (2012) Intrathecal PLC(beta3) oligodeoxynucleotides antisense 
potentiates acute morphine efficacy and attenuates chronic morphine tolerance. Brain Res 1472:38-44. CrossRef Medline

Reichling DB, Levine JD (2009) Critical role of nociceptor plasticity in chronic pain. Trends Neurosci 32:611-618. CrossRef Medline

Schneider JP, Kirsh KL (2010) Defining clinical issues around tolerance, hyperalgesia, and addiction: a quantitative and qualitative outcome study of long-term opioid dosing in a chronic pain practice. J Opioid Manag 6:385-395. CrossRef Medline

Sharma SK, Klee WA, Nirenberg M (1975a) Dual regulation of adenylate cyclase accounts for narcotic dependence and tolerance. Proc Natl Acad Sci U S A 72:3092-3096. CrossRef Medline

Sharma SK, Nirenberg M, Klee WA (1975b) Morphine receptors as regulators of adenylate cyclase activity. Proc Natl Acad Sci U S A 72:590-594. CrossRef Medline

Smrcka AV (2008) G protein betagamma subunits: central mediators of G protein-coupled receptor signaling. Cell Mol Life Sci 65:2191-2214. CrossRef Medline

Song MJ, Wang YQ, Wu GC (2009) Additive anti-hyperalgesia of electroacupuncture and intrathecal antisense oligodeoxynucleotide to interleukin-1 receptor type I on carrageenan-induced inflammatory pain in rats. Brain Res Bull 78:335341. CrossRef Medline

Su L, Wang C, Yu YH, Ren YY, Xie KL, Wang GL (2011) Role of TRPM8 in dorsal root ganglion in nerve injury-induced chronic pain. BMC Neurosci 12:120. CrossRef Medline

Sun JL, Xiao C, Lu B, Zhang J, Yuan XZ, Chen W, Yu LN, Zhang FJ, Chen G, Yan M (2013) CX3CL1/CX3CR1 regulates nerve injury-induced pain hypersensitivity through the ERK5 signaling pathway. J Neurosci Res 91: 545-553. CrossRef Medline
Taiwo YO, Levine JD (1989) Prostaglandin effects after elimination of indirect hyperalgesic mechanisms in the skin of the rat. Brain Res 492:397399. CrossRef Medline

Taiwo YO, Levine JD (1990) Direct cutaneous hyperalgesia induced by adenosine. Neuroscience 38:757-762. CrossRef Medline

Taiwo YO, Levine JD (1991) Further confirmation of the role of adenyl cyclase and of cAMP-dependent protein kinase in primary afferent hyperalgesia. Neuroscience 44:131-135. CrossRef Medline

Taiwo YO, Bjerknes LK, Goetzl EJ, Levine JD (1989) Mediation of primary afferent peripheral hyperalgesia by the cAMP second messenger system. Neuroscience 32:577-580. CrossRef Medline

Vanderah TW, Suenaga NM, Ossipov MH, Malan TP Jr, Lai J, Porreca F (2001) Tonic descending facilitation from the rostral ventromedial medulla mediates opioid-induced abnormal pain and antinociceptive tolerance. J Neurosci 21:279-286. Medline

Vulchanova L, Olson TH, Stone LS, Riedl MS, Elde R, Honda CN (2001) Cytotoxic targeting of isolectin IB4-binding sensory neurons. Neuroscience 108:143-155. CrossRef Medline

Willets JM, Challiss RA, Nahorski SR (2003) Non-visual GRKs: are we seeing the whole picture? Trends Pharmacol Sci 24:626-633. CrossRef Medline

Yang L, Wang S, Sung B, Lim G, Mao J (2008) Morphine induces ubiquitinproteasome activity and glutamate transporter degradation. J Biol Chem 283:21703-21713. CrossRef Medline

Yonemoto W, Garrod SM, Bell SM, Taylor SS (1993) Identification of phosphorylation sites in the recombinant catalytic subunit of cAMPdependent protein kinase. J Biol Chem 268:18626-18632. Medline 